\title{
Mapping of novel salt tolerance QTL in an Excalibur × Kukri doubled haploid wheat population
}

\author{
Muhammad A. Asif ${ }^{1,2} \cdot$ Rhiannon K. Schilling $^{1,2} \cdot$ Joanne Tilbrook ${ }^{1,2,3} \cdot$ Chris Brien ${ }^{1,4,5} \cdot$ Kate Dowling $^{1,4}$. \\ Huwaida Rabie $^{5,6} \cdot$ Laura Short $^{1,2}$. Christine Trittermann ${ }^{1,2}$. Alexandre Garcia ${ }^{1,2,4}$. Edward G. Barrett-Lennard ${ }^{7,8}$. \\ Bettina Berger ${ }^{2,4} \cdot$ Diane E. Mather $^{2}$. Matthew Gilliham ${ }^{2,9} \cdot$ Delphine Fleury $^{1,2} \cdot$ Mark Tester $^{1,2,10} \cdot$ Stuart J. Roy ${ }^{1,2}$ (D) \\ Allison S. Pearson ${ }^{1,2,9}$
}

Received: 13 April 2018 / Accepted: 14 July 2018 / Published online: 30 July 2018

(c) The Author(s) 2018

\begin{abstract}
Key message Novel QTL for salinity tolerance traits have been detected using non-destructive and destructive phenotyping in bread wheat and were shown to be linked to improvements in yield in saline fields.

Abstract Soil salinity is a major limitation to cereal production. Breeding new salt-tolerant cultivars has the potential to improve cereal crop yields. In this study, a doubled haploid bread wheat mapping population, derived from the bi-parental cross of Excalibur $\times$ Kukri, was grown in a glasshouse under control and salinity treatments and evaluated using highthroughput non-destructive imaging technology. Quantitative trait locus (QTL) analysis of this population detected multiple QTL under salt and control treatments. Of these, six QTL were detected in the salt treatment including one for maintenance of shoot growth under salinity $\left(Q G_{(1-5)}\right.$.asl-7A), one for leaf $\mathrm{Na}^{+}$exclusion ( $\left.Q N a . a s l-7 A\right)$ and four for leaf $\mathrm{K}^{+}$accumulation (QK.asl-2B.1, QK.asl-2B.2, QK.asl-5A and QK:Na.asl-6A). The beneficial allele for $Q G_{(1-5)}$.asl-7A (the maintenance of shoot growth under salinity) was present in six out of 44 mainly Australian bread and durum wheat cultivars. The effect of each QTL allele on grain yield was tested in a range of salinity concentrations at three field sites across 2 years. In six out of nine field trials with different levels of salinity stress, lines with alleles for $\mathrm{Na}^{+}$exclusion and/or $\mathrm{K}^{+}$maintenance at three QTL (QNa.asl-7A, QK.asl-2B.2 and QK:Na.asl-6A) excluded more $\mathrm{Na}^{+}$or accumulated more $\mathrm{K}^{+}$compared to lines without these alleles. Importantly, the $Q K$.asl-2B.2 allele for higher $\mathrm{K}^{+}$accumulation was found to be associated with higher grain yield at all field sites. Several alleles at other QTL were associated with higher grain yields at selected field sites.
\end{abstract}

\section{Introduction}

Soil salinity is a significant abiotic stress that limits the production of cereal crops worldwide (Flowers et al. 1997; Munns and Gilliham 2015; Rengasamy 2006; Roy et al. 2014). It has been estimated that more than $20 \%$ of irrigated and $8 \%$ of rainfed agricultural land is affected by salinity

Communicated by Mark E. Sorrells.

Muhammad A. Asif and Rhiannon K. Schilling: Joint first authors.

Electronic supplementary material The online version of this article (https://doi.org/10.1007/s00122-018-3146-y) contains supplementary material, which is available to authorized users.

Stuart J. Roy

stuart.roy@adelaide.edu.au

Extended author information available on the last page of the article
(FAO 2017; Hasegawa 2013; Rengasamy 2006). This area is expected to increase due to changing global climatic conditions, land clearing and irrigation practices causing rising water tables. The deleterious effects of soil salinity on the growth and development of cereals include poor germination rates, reduced plant growth, premature leaf senescence, less tillering and lower grain yields (Fricke and Peters 2002; Munns and Tester 2008; Roy et al. 2014).

To help mitigate the effects of salinity on crop yields, it is important to recognize that a number of sub-traits underpin plant salinity tolerance. To develop high-yielding salttolerant cultivars for salt-affected land, crops should contain favourable alleles for a number of these sub-traits (Flowers 2004; Gilliham et al. 2017; Roy et al. 2014). While multiple genes and quantitative trait loci (QTL) have been found to affect plant salt tolerance, there are only a few cases where the results of laboratory or glasshouse studies have been validated under field conditions (Genc et al. 2013; Munns 
et al. 2012). For results obtained under controlled conditions to be translated into outcomes for growers, it is important to investigate whether specific loci contribute to grain yield improvement under saline field conditions (Gilliham et al. 2017).

Greater salinity tolerance of plants has been reported to be associated with exclusion of $\mathrm{Na}^{+}$and $\mathrm{Cr}$ from the shoot (Genc et al. 2010; Poustini and Siosemardeh 2004; Rashid et al. 1999; Roy et al. 2014; Teakle and Tyerman 2010), maintenance of $\mathrm{K}^{+}$homoeostasis (Chen et al. 2005; Munns and Tester 2008), accumulation of toxic ions in the vacuole (Munns et al. 2016; Munns and Tester 2008), accumulation of compatible solutes (Flowers and Colmer 2008; Hasegawa et al. 2000; Munns and Tester 2008) and/or ability to maintain shoot growth during the early phase of salt stress before ions accumulate to toxic concentrations in the shoot (shoot ion-independent tolerance or osmotic tolerance) (Munns and Tester 2008; Roy et al. 2014).

Of the salt tolerance mechanisms listed above, shoot ionindependent tolerance has received relatively little research attention. Using non-destructive plant imaging technologies, genetic variation has been observed for shoot tolerance mechanisms not related to shoot ion concentration in barley (Hordeum vulgare) (Tilbrook et al. 2017), bread wheat (Takahashi et al. 2015), chickpea (Atieno et al. 2017), durum wheat (Sirault et al. 2009), rice (Al-Tamimi et al. 2016; Campbell et al. 2015) and Triticum monococcum (Rajendran et al. 2009). In rice, a genome-wide association study (GWAS) detected marker-trait associations with shoot ion-independent tolerance, with a number of candidate genes suggested (Al-Tamimi et al. 2016). However, to date, no genes for shoot ion-independent tolerance have been identified in bread wheat.

Here we screened a bread wheat doubled haploid (DH) mapping population (Excalibur $\times$ Kukri) in the glasshouse under control and salinity treatments to identify novel QTL for a number of salinity tolerance sub-traits. Promising QTL from the glasshouse trials were then validated in the field by testing a set of Excalibur $\times$ Kukri DH lines across a range of salinity concentrations at multiple field trial sites for 2 years.

\section{Materials and methods}

\section{Plant materials}

A DH mapping population of Excalibur $\times$ Kukri was developed from the $F_{1}$ generation of a cross between single plants of two Australian wheat cultivars mixed haplotypes Excalibur (RAC177/Uniculm492//RAC311S) and Kukri (76ECN44/76ECN36//RAC549/Madden/6*RAC177). The Excalibur parent used in this population was a single plant known as Excalibur-198. This population was previously used for mapping loci affecting ion accumulation (Edwards 2012; Shavrukov et al. 2011), nematode resistance (Jayatilake et al. 2013) and metabolite abundance (Hill et al. 2013, 2015). Excalibur is a drought-tolerant wheat cultivar and has high yields in the wheat belt of South Australia but produces low-quality grain and is susceptible to rust. Kukri is a hard-white wheat cultivar that has low drought and heat tolerance but produces excellent quality grain and is resistant to rust (Izanloo et al. 2008). The Excalibur and Kukri parents, along with $212 \mathrm{DH}$ lines, were used for controlled glasshouse phenotyping. A set of $20 \mathrm{DH}$ lines from this population with high and low shoot ion-independent tolerance (maintenance of growth during early phase (1-5 days) of salt treatment) and 18 lines with high and low ion-dependent tolerance (leaf $\mathrm{Na}^{+}$exclusion) along with both parents were used for field trials (Supplementary Table 1). Three plants from each of 44 Australian bread wheat cultivars and one landrace were genotyped for a single nucleotide polymorphism (SNP) (X2279012.58AC) that was found to be linked with a shoot ion-independent tolerance QTL on chromosome $7 \mathrm{~A}\left(Q G_{(1-5)} \cdot a s l-7 A\right)$. This genotyping was conducted using two forward primers 5'-GAAGGTGACCAAGTTCAT GCTGGGGCGATAAGGACGCGGA-3' and 5'-GAAGGT CGGAGTCAACGGATTGGGCGATAAGGACGCGGC-3' (including the underlined FAM and VIC tails, respectively) and a common primer 5'-CCTTACGCATGTAAGCATTTC CCGAA-3' in a Kompetitive Allele Specific PCR (KASPTM) assay (www.lgcgroup.com/our-science/genomics-solutions/ genotyping/kasp-genotyping-chemistry).

\section{Non-destructive glasshouse-based phenotyping}

A phenotyping experiment was conducted from late winter to early spring (29 August to 26 September 2011) using a fully automated conveyer system containing carts for pots of plants within a temperature-controlled Smarthouse (The Plant Accelerator ${ }^{\circledR}$, Adelaide, Australia; longitude: 138.64, latitude: -34.97$)$. The experiment was a partially replicated design with $20 \%$ of the population duplicated and the parents (Excalibur and Kukri) replicated six times. Seeds of the Excalibur and Kukri parents along with 212 Excalibur $\times$ Kukri DH lines were imbibed in reverse osmosis (RO) water at room temperature for $2 \mathrm{~h}$ and placed in the dark at $4{ }^{\circ} \mathrm{C}$ for $48 \mathrm{~h}$. Four seeds were sown in a white pot $(19.5 \mathrm{~cm}$ height $\times 15 \mathrm{~cm}$ diameter, Berry Plastics Corporation, Evansville, USA) filled with $2.6 \mathrm{~kg}$ of soil potting mixture (50\% (v/v) University of California mix, 35\% (v/v) peat mix and $15 \%(\mathrm{v} / \mathrm{v})$ clay loam soil from Angle Vale, South Australia, Australia. After sowing, plants were grown under natural light with temperatures at $22{ }^{\circ} \mathrm{C}$ days and $15{ }^{\circ} \mathrm{C}$ night. All the pots were arranged according to a split-plot design, which was constructed using DiGGer (Coombes 2009) and dae (Brien 2015b). In the design (multiline experiment 3), 
two carts/pots in the same position in adjacent lanes form a main plot (Brien et al. 2013). The main-plot design is a blocked, nearly trend-free, partially replicated design that assigns lines to main plots; the subplot design randomizes conditions (control, salt) to the two carts in each main plot.

Plants were thinned to one seedling per pot at the second leaf stage. At the emergence of the third leaf (14 days after planting), pots were loaded into carts on the Smarthouse conveyer system maintaining the split-plot design. Seedlings were watered to weight every second day to maintain the soil water content at $17 \%$ gravimetric water content. At emergence of the fourth leaf (18 days after planting), $\mathrm{NaCl}$ solution was added to the saucer to reach a final concentration of $100 \mathrm{mM} \mathrm{NaCl}$ in the soil solution. Pots were not watered again until the soil water content went below $17 \%$ $(\mathrm{g} / \mathrm{g})$. Each pot was then watered automatically to maintain the soil water content at $17 \%(\mathrm{~g} / \mathrm{g})$ and salinity at $100 \mathrm{mM}$ $\mathrm{NaCl}$. This was achieved by the electronic conveyer system weighing the pot every second day on industrial scales (Bizerba, Balingen, Germany) and applying the appropriate amount of RO water.

The LemnaTec Scanalyser 3D (LemnaTec GmbH, Aachen, Germany) at The Plant Accelerator ${ }^{\circledR}$ was used for non-destructive measurements of plant growth. Three 5 megapixel red-green-blue (RGB) images of each plant were recorded every sampling day, one from the top view and two from the side view at a $90^{\circ}$ rotation to each other (Golzarian et al. 2011; Rajendran et al. 2009; Takahashi et al. 2015). Imaging started 4 days before salt treatment and continued for 10 days after salt application. After 10 days of salt treatment, the fully expanded fourth leaf was sampled for ion concentration $\left(\mathrm{Na}^{+}\right.$and $\left.\mathrm{K}^{+}\right)$and the youngest fully emerged leaf was sampled for DNA extraction and genotyping.

\section{Shoot ion-independent tolerance calculation}

The total shoot pixel area derived from the three RGB images were used to calculate the projected shoot area (PSA, kpixels) of each plant (Golzarian et al. 2011; Rajendran et al. 2009). A linear correlation between shoot biomass and PSA has been observed in Triticum monococcum (Golzarian et al. 2011) and bread wheat (Takahashi et al. 2015). To calculate the growth rate of an individual plant, a cubic smoothing spline was fitted to the PSA for the plant as measured over time, using the $\mathrm{R}$ function smooth.splines with degrees of freedom $(d f)$ set to 4 (Al-Tamimi et al. 2016). The relative growth rate (RGR) was calculated for each plant for each day it was imaged as RGR $\left(\right.$ kpixels $\mathrm{d}^{-1}$ kpixels $\left.^{-1}\right)=(\mathrm{d} \ln (A) / \mathrm{d} t)$, where $A$ is the projected shoot area, $d \ln (A)$ is the difference in logarithm projected shoot area over the time period $\mathrm{d} t$ ). Also, the RGR was calculated for each plant for the intervals $1-5$ days after salt treatment. The ability to maintain growth after salt application (1-5 days) was calculated for each DH line or parent as the ratio of the RGR for the salt-treated plant divided by the RGR for the control plant.

\section{Statistical analysis of imaging data}

In the glasshouse, the RGR for the intervals 1-5 days after salt treatment were analysed by fitting mixed models using asreml (Butler et al. 2009) and asremlPlus (Brien 2015a). The maximal model included fixed effects for genotype, treatment and their interaction, random components for zones, main plots and residual variation and terms for curved trend and deviations from trend for lanes and positions. Random terms were tested for significance and removed if not significant. The shoot ion-independent tolerance was analysed using a model with fixed genotype effects and random zone and residual variation.

\section{Measurements of leaf $\mathrm{Na}^{+}$and $\mathrm{K}^{+}$concentrations}

The fourth leaf, which was fully expanded under salt treatment, was harvested after 10 days of salt treatment. Leaf fresh weight was measured and the samples dried in an oven for 2 days at $65{ }^{\circ} \mathrm{C}$ before the dry weight was recorded. Dried leaves were digested in $10 \mathrm{~mL}$ of $1 \%(\mathrm{v} / \mathrm{v}) \mathrm{HNO}_{3}$ at $85^{\circ} \mathrm{C}$ for $4 \mathrm{~h}$ in a 54-well Hotblock (Environmental Express, Mount Pleasant, SC, USA). The concentration of $\mathrm{Na}^{+}$and $\mathrm{K}^{+}$was measured using a flame photometer (Model 420 Sherwood, Cambridge, UK).

\section{Field-based phenotyping}

Field trials were conducted at Cunderdin, Western Australia (WA) (2014 and 2015), Whitwarta, South Australia (SA) (2014 and 2015) and Coomandook (SA) (2015). Each trial consisted of a low and high salinity site ranging from 100 to $500 \mathrm{~m}$ apart within the same paddock (Table 1). The total area of each site was up to 0.7 ha with the Excalibur $\times$ Kukri experiment comprising $20 \%$ of this area. Growing season rainfall and temperature values (Supplementary Table 2) and rainfall and temperature values for each month (Supplementary Figure 1) were obtained from the Bureau of Meteorology (BOM) for each site. For each trial, the plots were arranged in a rectangular array of rows and ranges (12 ranges by 10 rows) and a spatially optimized row-column design was used to assign three replicates of each of 48 lines and the two parents to the plots. The designs were obtained using the $\mathrm{R}$ statistical software environment (R Development Core Team 2014) with the DiGGer package (Coombes 2009). In SA, $70 \mathrm{~g}$ of seed was sown per plot for an initial plot size of $1.32 \mathrm{~m} \times 7 \mathrm{~m}$ at sowing and a final plot size of $1.32 \mathrm{~m} \times 5 \mathrm{~m}$ reduced by herbicide application prior to stem elongation. In WA, $50 \mathrm{~g}$ of seed was sown per plot with an initial plot size of $1.32 \mathrm{~m} \times 6 \mathrm{~m}$ at sowing and a final plot 
Table 1 The apparent electrical conductivity $\left(\mathrm{EC}_{\mathrm{a}}, \mathrm{mS} / \mathrm{m}\right)$ measured in the horizontal mode at $0-50 \mathrm{~cm}\left(\mathrm{EC}_{\mathrm{ah}}\right)$ and vertical mode at $0-100 \mathrm{~cm}\left(\mathrm{EC}_{\mathrm{av}}\right)$ in October (Whitwarta and Coomandook), August

\begin{tabular}{|c|c|c|c|c|c|c|c|c|c|c|c|c|c|c|c|}
\hline \multirow[t]{2}{*}{ Year } & \multirow[t]{2}{*}{ Location } & \multirow[t]{2}{*}{ Site } & \multicolumn{2}{|c|}{$\begin{array}{l}\text { EM38 value } \\
0-50 \mathrm{~cm} \\
\left(\mathrm{EC}_{\mathrm{ah}}\right)(\mathrm{mS} / \mathrm{m})\end{array}$} & \multicolumn{2}{|c|}{$\begin{array}{l}\text { EM38 value } \\
0-100 \mathrm{~cm} \\
\left(\mathrm{EC}_{\mathrm{av}}\right)(\mathrm{mS} / \mathrm{m})\end{array}$} & \multicolumn{2}{|c|}{$\begin{array}{l}\text { Soil solution } \\
(\mathrm{mM}) 0-25 \mathrm{~cm}\end{array}$} & \multicolumn{2}{|c|}{$\begin{array}{l}\text { Soil solu- } \\
\text { tion }(\mathrm{mM}) \\
25-50 \mathrm{~cm}\end{array}$} & \multicolumn{2}{|c|}{$\begin{array}{l}\text { Soil EC }{ }_{1: 5} \\
(\mathrm{dS} / \mathrm{m}) 0-25 \mathrm{~cm}\end{array}$} & \multicolumn{2}{|c|}{$\begin{array}{l}\text { Soil EC } \mathrm{E}_{1: 5} \\
(\mathrm{dS} / \mathrm{m}) \\
25-50 \mathrm{~cm}\end{array}$} & \multirow[t]{2}{*}{$n$} \\
\hline & & & Mean & SEM & Mean & SEM & Mean & SEM & Mean & SEM & Mean & SEM & Mean & SEM & \\
\hline \multirow[t]{4}{*}{2014} & \multirow[t]{2}{*}{ Whitwarta } & Low salt & 53 & 0.4 & 80 & 0.5 & 113 & 0.03 & 104 & 0.8 & 0.13 & 0.0004 & 0.18 & 0.0019 & 504 \\
\hline & & High salt & 100 & 0.3 & 157 & 0.4 & 141 & 0.7 & 179 & 0.7 & 0.18 & 0.0008 & 0.34 & 0.0030 & 504 \\
\hline & \multirow[t]{2}{*}{ Cunderdin } & Low salt & nd & nd & nd & nd & nd & nd & nd & nd & nd & nd & nd & nd & nd \\
\hline & & High salt & 221 & 1.6 & 276 & 1.3 & 445 & 11 & 646 & 12 & 0.79 & 0.020 & 1.46 & 0.0235 & 585 \\
\hline \multirow[t]{6}{*}{2015} & \multirow[t]{2}{*}{ Coomandook } & Low salt & 136 & 0.5 & 90 & 0.4 & 43 & 0.1 & 44 & 0.1 & 0.03 & 0.0003 & 0.06 & 0.0007 & 504 \\
\hline & & High salt & 151 & 1.0 & 113 & 1.0 & 308 & 1.0 & 244 & 1.0 & 0.45 & 0.0100 & 0.57 & 0.0130 & 396 \\
\hline & \multirow[t]{2}{*}{ Whitwarta } & Low salt & 60 & 0.7 & 41 & 0.4 & 33 & 0.2 & 40 & 0.03 & 0.09 & 0.0003 & 0.11 & 0.0001 & 504 \\
\hline & & High salt & 175 & 1.3 & 124 & 1.1 & 70 & 1.6 & 119 & 4.5 & 0.27 & 0.0098 & 0.40 & 0.0113 & 504 \\
\hline & \multirow[t]{2}{*}{ Cunderdin } & Low salt & 70 & 1.0 & 98 & 1.2 & 61 & 0.5 & 90 & 1.5 & 0.11 & 0.0020 & 0.25 & 0.0060 & 585 \\
\hline & & High salt & 216 & 1.5 & 261 & 1.3 & 268 & 5.0 & 349 & 4.3 & 0.50 & 0.0141 & 1.02 & 0.0157 & 598 \\
\hline
\end{tabular}

Values derived from calibration curves between measured soil $\mathrm{EC}_{1: 5}$ and salinity of the soil solution with EM38 values at $0-50 \mathrm{~cm}$ for Cunderdin and $0-100 \mathrm{~cm}$ for Whitwarta and Coomandook

$n$ the number of plots tested, $n d$ no data

size of $1.32 \mathrm{~m} \times 4 \mathrm{~m}$. Standard agronomic practices were used including pest and disease treatments, weed control and fertilizer applications. To reduce potential crown rot issues, the seed sown at Cunderdin in 2014 was treated with EverGol ${ }^{\circledR}$ Prime (Penflufen: $240 \mathrm{~g} / \mathrm{L}$ active ingredient) at a rate of $6 \mathrm{~mL}$ of EverGol Prime per $\mathrm{kg}$ of seed.

In July and October of each year, the apparent electrical conductivity $\left(\mathrm{EC}_{\mathrm{a}}, \mathrm{mS} / \mathrm{m}\right)$ at two soil depths (0-50 and $0-100 \mathrm{~cm}$ ) of each low and high salinity trial was measured using a handheld EM38 Geonics device (Cunderdin only) or a vehicle-fitted EM38 Geonics device (Precision Ag Services, Minalton, Australia) (Whitwarta and Coomandook), except in 2014, where the low salinity site at Cunderdin was not measured (Supplementary Figure 2). At Whitwarta and Coomandook, based on the EM38 maps at 0-100 cm, soil was collected from a depth of $0-25$ and $25-50 \mathrm{~cm}$ in regions of the trial site corresponding to EM38 values ranging every 5 th percentile (low and high salt) from the minimum to maximum recorded EM38 value for each trial area. At Cunderdin, based on the EM38 maps at $0-50 \mathrm{~cm}$, soil was collected from $0-25$ and $25-50 \mathrm{~cm}$ at locations of the trial at every 5th percentile (high salt 2014), every 6.7th percentile (low salt 2015) and every 3.5 th percentile (high salt 2015). Soil gravimetric water content $(\mathrm{g} / \mathrm{g})$ was determined by recording the fresh weight and weight after drying in an oven at $80^{\circ} \mathrm{C}$ for 3 days. Soil electrical conductivity $\left(\mathrm{EC}_{1: 5}\right)$ and $\mathrm{pH}$ (water) were measured using a CyberScan PC510 m (Eutech Instruments, Thermo Fisher Scientific Inc., Waltham, MA, USA) in a 1:5 (soil:water) extract after shaking for $1 \mathrm{~h}$ and settling for $30 \mathrm{~min}$. The concentration of $\mathrm{Na}^{+}, \mathrm{K}^{+}$and $\mathrm{Cl}^{-}$was measured in the soil:water extract
(Cunderdin in 2014) and September (Cunderdin in 2015), the calculated salinity of the soil solution $(\mathrm{mM})$ and soil electrical conductivity $(\mathrm{dS} / \mathrm{m})$ at $0-25$ and $25-50 \mathrm{~cm}$ 
(1) random row and column terms, (2) first-order autocorrelation for rows and columns, (3) a fixed effect term for lines and (4) covariates as described in Supplementary Table 4 and that included EM38 and $\mathrm{EC}_{1: 5}$ measurements. REML ratio tests were carried out for both the rows and columns autocorrelation and when not significantly removed from the model.

\section{DNA extraction and KASP ${ }^{\mathrm{TM}}$ genotyping}

Genomic DNA was extracted from the youngest fully expanded leaf using the phenol/chloroform method (Pallotta et al. 2000; Rogowsky et al. 1991). DNA was quantified using a NanoDrop 1000 spectrophotometer (Thermo Fisher Scientific, Wilmington, DE) and diluted to $1 \mathrm{ng} / \mu$ l for use in the KASPTM assay (www.lgcgroup.com/our-science/genom ics-solutions/genotyping/kasp-genotyping-chemistry).

\section{Construction of Excalibur $\times$ Kukri DH genetic map}

A genetic linkage map of the Excalibur $\times$ Kukri DH population with 233 lines was previously constructed by Edwards (2012) and updated by Jayatilake et al. (2013) with new markers for 182 lines. Additional 12 KASP $^{\text {TM }}$ markers were developed using sequencing data from the $9 \mathrm{~K}$ Wheat Illumina Infinium iSelect genotyping array (Cavanagh et al. 2013); KASP ${ }^{\text {TM }}$ markers from the Avalon $\times$ Cadenza genetic linkage map (Allen et al. 2013) and CerealDB database (http://www.cerealsdb.uk.net/cerealgenomics/CerealsDB/ kasp_mapped_snps.php/) were added to the existing Excalibur $\times$ Kukri DH genetic map using MapManager QTXb20 (Manly et al. 2001). Recombination frequencies were converted to $\mathrm{cM}$ using the Kosambi mapping function (Kosambi 1943), and the marker order was optimized using the recombination counting and ordering (RECORD) program (Van Os et al. 2005).

A second genetic linkage map for the Excalibur $\times$ Kukri $\mathrm{DH}$ population was developed using genotyping by sequencing (GBS) conducted by Diversity Arrays Technology (DArT) Pty Ltd (Canberra, Australia) using the DArTseq assay (http://www.diversityarrays.com/). The two genetic linkage maps were combined together using the combineMap function of R/ASMap (version 0.4-7) (Taylor 2015). The combined map was curated by removing markers having $>20 \%$ missing data and significant segregation distortion ( $>0.6$ or $<0.4(p=0.05)$. Similarly, the lines that showed a high observed count of crossovers (threshold $=100$ ) were also removed. The final integrated linkage map consisted of 155 individuals with 3503 markers assigned to 27 linkage groups, representing all chromosomes, except 4B, with a total length of $2707 \mathrm{cM},(1140,961$ and $606 \mathrm{cM}$ for the A, $\mathrm{B}$ and D genomes, respectively) (Supplementary Table 5). Despite numerous attempts, and adjustment of parameters in the mapping programs, it was not possible to identify any polymorphisms on chromosome $4 \mathrm{~B}$.

\section{Quantitative trait loci (QTL) analysis}

Using WinQTLCart version 2.5 (Wang et al. 2007) (Model 6 standard analysis with 5 control markers and a window size of $10 \mathrm{cM}$ ), composite interval mapping (Zeng 1994) was performed on the 212 lines phenotyped in 2011 using genotyping data obtained in 2014 of 129 lines (Jayatilake et al. 2013) (Supplementary Table 6) (Wang et al. 2007). Log of odds (LOD) thresholds were determined with 1000 permutations (Churchill and Doerge 1994) at a $1 \mathrm{cM}$ walk $(p=0.05)$. Significant QTL were summarized with their position on a linkage group, LOD score, magnitude and directions of their estimated additive effects and their contribution to the genetic variance. The notation for individual QTL followed the recommended format for wheat: Qphenotype.lab-chromosome.QTL number with 'asl' signifying 'Adelaide Salt Lab'. The $G_{(1-5)}$ refers to shoot ion-independent growth calculated over 1-5 days, $C R G R$ the relative growth rate under control condition, $\mathrm{Na}$ the leaf $\mathrm{Na}^{+}$concentration and $\mathrm{K}$ the leaf $\mathrm{K}^{+}$concentration. Unique QTL were defined as those where a subset of correlated traits mapped within $15 \mathrm{cM}$ of one another (Sewell et al. 2000, 2002).

\section{Determining the effect of allele on phenotype in the field}

To determine the effect of the salinity tolerance alleles on yield and performance in the field, the genotypic and field trials phenotypic data were aligned. For the Excalibur $\times$ Kukri DH lines selected based on their glasshouse phenotype (high or low shoot ion-independent tolerance and/or low and high leaf $\mathrm{Na}^{+}$concentration), the statistically adjusted mean value for the phenotypic traits measured at each field trial (leaf $\mathrm{Na}^{+}$and $\mathrm{K}^{+}$concentrations and grain yield) was aligned with the genotypic data of each line. For each significant marker of a QTL detected in the glasshouse experiment, the DH lines were sorted by their allele $(\mathrm{E}=$ Excalibur - or $\mathrm{K}=\mathrm{Kukri})$. The performance of field grown lines, with either the Excalibur or Kukri alleles, was assessed based on whether their phenotype was consistent with that of the parents observed in the glasshouse. The mean value for each trait for lines grouped with either the $\mathrm{E}$ or $\mathrm{K}$ allele was calculated and the $\%$ increase or decrease from that allele for each trait was determined.

\section{Physical mapping of the QTL}

To generate a list of genes underlying specific QTL, all the markers (Supplementary Table 7) within the detected region, that were up to 2 LOD drops from the maximum likelihood 
value of selected QTL, were physically positioned on the wheat genome sequence. The appropriate SNP-bearing sequences were probed to the entire bread wheat NRGene genome assembly version 1.0 (International Wheat Genome Sequencing Consortium, https://wheat-urgi.versailles.inra. $\mathrm{fr} /$ Seq-Repository/Assemblies) using an in-house BLAST portal. The limit of acceptance of assignment was based on the query sequence having a cumulative identity percentage of similarity ( $>96 \%$ ) and a cumulative alignment length percentage of matches (90-100\%) to the hit from the sequence database. The wheat genome scaffolds containing the marker, as well as the genome scaffolds bridging the region between the two flanking markers, were retrieved from the BLAST searches and used to find expressed genes on the scaffolds, using POTAGE (PopSeq Ordered Triticum aestivum Gene Expression) (Suchecki et al. 2017) and an in-house tool, DAWN (diversity among wheat genomes), developed at the Australian Centre for Plant Functional Genomics.

DAWN is a bioinformatics tool, which utilizes the International Wheat Genome Sequencing Consortium (IWGSC; www.wheatgenome.org/2 bread wheat scaffolds version 3, pseudomolecule assembly version 0.4 (https://wheat-urgi. versailles.inra.fr/) to aggregate a wide range of bread wheat genomic and transcriptomic data. This includes a Bioplatforms Australia (BPA) whole-genome sequencing (WGS) dataset of 16 Australian wheat cultivars (Edwards et al. 2012), including Excalibur and Kukri. DAWN includes the location of high confidence gene predictions from International Wheat Genome Sequencing Consortium (2014) as well as RNA-Seq expression data from five wheat tissues (root, leaf, stem, spike and grain), taken at three developmental stages (seedling, vegetative and flowering) under normal growth conditions (https://urgi.versailles.inra.fr/ files/RNASeqWheat/2 (Choulet et al. 2014; Rustenholz et al. 2011). POTAGE integrates map location with gene expression and inferred functional annotation and visualizes these data through a web browser interface (Suchecki et al. 2017).

\section{Results}

\section{Glasshouse phenotyping}

The parents Excalibur and Kukri had on average 30 and 24\% reduction in PSA, respectively, after 10 days of $100 \mathrm{mM}$ $\mathrm{NaCl}$ when compared to control plants (Fig. 1). The ratio of relative growth rates $\left(\mathrm{RGR}_{\text {salt }} / \mathrm{RGR}_{\text {control }}\right)$ after 5 days of salt treatment was used to determine the ability of each line to maintain growth. The range of shoot ion-independent tolerance values observed over the first 5 days of salt treatment in the DH population was from 0.66 to 1.09 . Kukri and Excalibur had relative growth rates of 0.88 and 0.78 , respectively (Fig. 2a).

The fourth leaf ion concentration measured in the $\mathrm{DH}$ population had a skewed distribution for $\mathrm{Na}^{+}(\mu \mathrm{mol} / \mathrm{g}$ DW $)$ accumulation, with 88 lines having a lower $\mathrm{Na}^{+}$concentration than either parent. The mean fourth leaf $\mathrm{Na}^{+}$accumulation for Excalibur was $56 \pm 9.02 \mu \mathrm{mol} \mathrm{Na}^{+} / \mathrm{g} \mathrm{DW}$ and $110 \pm 27.63 \mu \mathrm{mol} \mathrm{Na} / \mathrm{g}$ DW for Kukri with a range of 25-315 $\mu \mathrm{mol} \mathrm{Na} / \mathrm{g}$ DW in the DH lines (Fig. 2b). A normal distribution for $\mathrm{K}^{+}$accumulation was observed (Fig. 2c), with Excalibur accumulating $1411 \pm 51 \mu \mathrm{mol} \mathrm{K}^{+} / \mathrm{g} \mathrm{DW}$ and Kukri accumulating $1275 \pm 36 \mu \mathrm{mol} \mathrm{K} / \mathrm{g}$ DW. The DH lines had a range of $917-1566 \mu \mathrm{mol} \mathrm{K} / \mathrm{g}$ DW.

\section{QTL for salinity tolerance traits in the glasshouse}

Under both salt and control treatments, 15 QTL were detected at 10 unique loci with LOD scores ranging between 2.6 and 12.9 (Table 2, Fig. 3). A range of phenotypic variation and additive effects were observed for the individual QTL (Table 2).

A single QTL for the ability to maintain growth under salinity was mapped on chromosome $7 \mathrm{~A}\left(Q G_{(1-5)}\right.$. asl-7A) with a LOD score of 5.0. It accounted for $14.1 \%$ of the phenotypic variation and had a positive effect from Excalibur (Table 2).

In the control treatment, two QTL were detected for RGR (1-5) on chromosomes 5A (QCRGR.asl-5A) and 7A (QCRGR.asl-7A) with LOD scores of 12.9 and 3.6, respectively (Table 2). These two QTL accounted for 29.8 and $7 \%$ of the phenotypic variation and the additive effect attributed with these QTL was small. These two QTL were not observed in the salt-treated plants.

A total of four QTL were detected for fourth leaf $\mathrm{Na}^{+}$ concentration including one QTL in salt-treated plants and three in the control treatment (Table 2). The QTL for $\mathrm{Na}^{+}$ concentration in the fourth leaf of salt-treated plants was located on chromosome 7A (QNa.asl-7A), with a LOD of 3.7 and $11.3 \%$ total phenotypic variation. The additive effect was -15.7 , indicating that Excalibur is a better excluder of $\mathrm{Na}^{+}$than Kukri. The three QTL detected in the control treatment were mapped on chromosomes $1 \mathrm{~A}$ (QNa.asl-1A.1 and QNa.asl-1A.2) and 6A (QNa.asl-6A) with LOD scores of 3.3, 5.9 and 2.7, respectively. The phenotypic variances for QNa.asl-1A.1, QNa.asl-1A.2 and QNa.asl-6A were 10.1, 18.2 and $4.9 \%$, respectively, with additive effects of 14.5 , -16.6 and 4.6, respectively. This suggests the Kukri alleles at QNa.asl-1A.1 and QNa.asl-6A, and the Excalibur allele at QNa.asl-1A.2 are linked to $\mathrm{Na}^{+}$exclusion.

For fourth leaf $\mathrm{K}^{+}$concentration, three QTL were detected in the salt-treated plants: on chromosomes $2 \mathrm{~B}$ (QK.asl-2B.1 and QK.asl-2B.2) and chromosome 5A (QK.asl-5A), with LOD scores of 3.8, 6.1 and 12.9, 

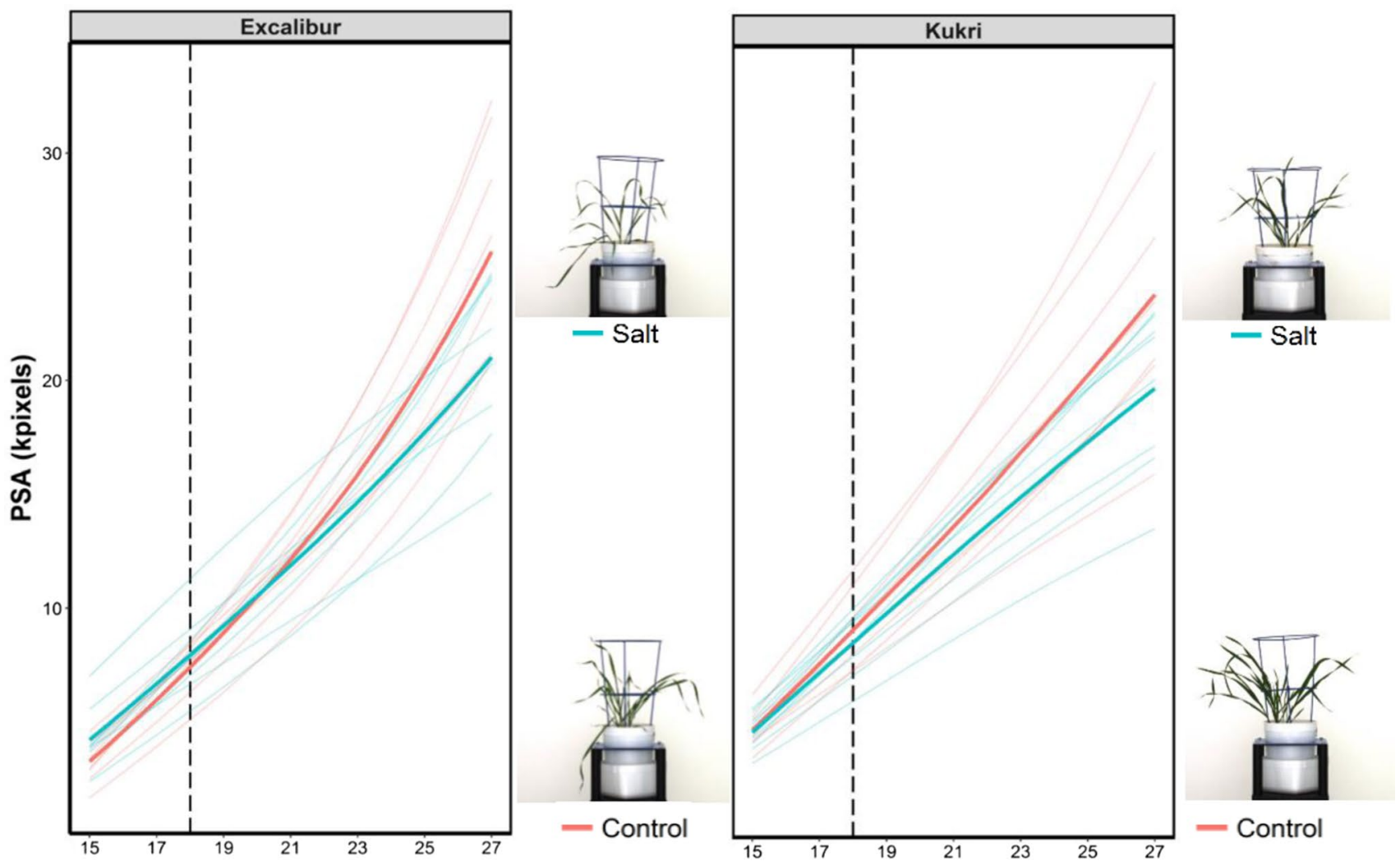

\section{Time after sowing (days)}

Fig. 1 The projected shoot area (PSA) of Excalibur and Kukri plants under control (red line) and salt stress $(100 \mathrm{mM} \mathrm{NaCl}$, blue line) from days 15 to 27 after sowing. The RGB side-view images of plants showing the difference between growth of control and salt-treated plants. The vertical dotted line indicates the time point of salt application. Bold red and blue lines represent the mean values while the other ones are the individual replicates (a)

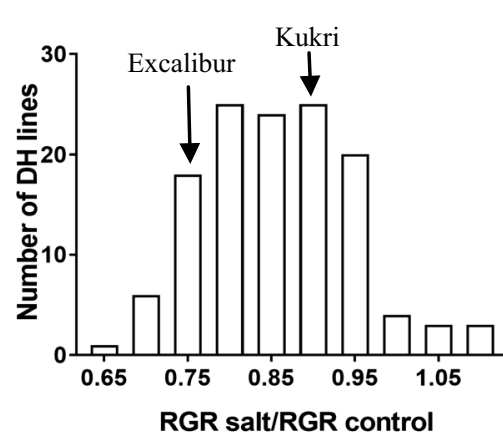

(b)

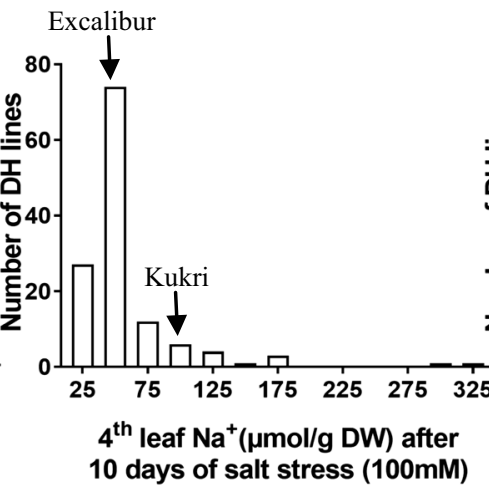

(c)

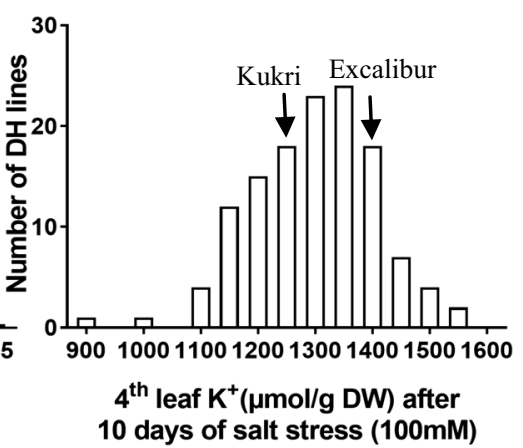

Fig. 2 Frequency distribution of a shoot ion-independent tolerance (days 1-5) and fourth leaf $\mathbf{b ~} \mathrm{Na}^{+}$accumulation ( $\mu \mathrm{mol} / \mathrm{g} \mathrm{DW}$ ) and $\mathbf{c}$ $\mathrm{K}^{+}$accumulation ( $\mu \mathrm{mol} / \mathrm{g} \mathrm{DW}$ ) measured after 10 days of salt stress

respectively. The phenotypic variances explained by these QTL were 8.1, 12.1 and $28.2 \%$, respectively (Table 2). One of the QTL on chromosome 2B (QK.asl-2B.2) had
$(100 \mathrm{mM})$ in the Excalibur $\times$ Kukri $\mathrm{DH}$ population. Arrows indicate the trait mean for parents, Excalibur and Kukri

the additive effect $(-50.0)$ being inherited from Kukri, while the second QTL on chromosome 2B (QK.asl-2B.1) and the QTL on chromosome 5A (QK.asl-5A) showed the 
Table 2 QTL for salt tolerance sub-traits in the Excalibur $\times$ Kukri DH mapping population under control and salt stress $(100 \mathrm{mM} \mathrm{NaCl}$ for 10 days). Trait name, QTL name, treatment, chromosome (Chr), posi-

\begin{tabular}{|c|c|c|c|c|c|c|c|c|}
\hline Trait & QTL & Treatment & Chr & Position & Marker & LOD & Additive & $R^{2}$ \\
\hline Growth $_{(1-5)}$ & $Q G_{(1-5)} \cdot$ asl-7A & Salt/control & 7A & 112.31 & $\mathrm{X} 2279012.58 \mathrm{AC}$ & 5.0 & 0.035 & 14.1 \\
\hline RGR & QCRGR.asl-5A & Control & $5 \mathrm{~A}$ & 126.21 & X1264710.28CG & 12.9 & 0.006 & 29.8 \\
\hline RGR & QCRGR.asl-7A & Control & $7 \mathrm{~A}$ & 99.41 & X1116135.61GA & 3.6 & -0.004 & 7.0 \\
\hline $\mathrm{Na}^{+} \mu \mathrm{mol} / \mathrm{g} \mathrm{DW}$ & QNa.asl-7A & Salt & $7 \mathrm{~A}$ & 75.01 & wmc0017 & 3.7 & -15.7 & 11.3 \\
\hline $\mathrm{Na}^{+} \mu \mathrm{mol} / \mathrm{g} \mathrm{DW}$ & QNa.asl-1A.1 & Control & $1 \mathrm{~A}$ & 106.61 & X2264210.64CG & 3.3 & 14.5 & 10.1 \\
\hline $\mathrm{Na}^{+} \mu \mathrm{mol} / \mathrm{g} \mathrm{DW}$ & QNa.asl-1A.2 & Control & $1 \mathrm{~A}$ & 120.41 & X1125323.58TG & 5.9 & -16.6 & 18.2 \\
\hline $\mathrm{Na}^{+} \mu \mathrm{mol} / \mathrm{g} \mathrm{DW}$ & QNa.asl-6A & Control & $6 \mathrm{~A}$ & 29.91 & X1127808.37CG & 2.7 & 4.6 & 4.9 \\
\hline $\mathrm{K}^{+} \mu \mathrm{mol} / \mathrm{g} \mathrm{DW}$ & QK.asl-2B.1 & Salt & $2 \mathrm{~B}$ & 52.61 & X1103701.44AG & 3.8 & 39.7 & 8.1 \\
\hline $\mathrm{K}^{+} \mu \mathrm{mol} / \mathrm{g} \mathrm{DW}$ & QK.asl-2B.2 & Salt & $2 \mathrm{~B}$ & 87.81 & X1022175.20CT & 6.1 & -50.0 & 12.1 \\
\hline $\mathrm{K}^{+} \mu \mathrm{mol} / \mathrm{g} \mathrm{DW}$ & QK.asl-5A & Salt & $5 \mathrm{~A}$ & 125.51 & Vrn-A1 & 12.9 & 57.4 & 28.2 \\
\hline $\mathrm{Na}^{+}: \mathrm{K}^{+} \mathrm{DW}$ & QNa:K.asl-5A.1 & Control & $5 \mathrm{~A}$ & 172.21 & X1130301.5CT & 5.0 & -0.020 & 13.8 \\
\hline $\mathrm{Na}^{+}: \mathrm{K}^{+} \mathrm{DW}$ & QNa:K.asl-5A.2 & Control & $5 \mathrm{~A}$ & 189.81 & X1083587.10GA & 3.0 & 0.015 & 8.0 \\
\hline $\mathrm{Na}^{+}: \mathrm{K}^{+} \mathrm{DW}$ & QNa:K.asl-6A & Control & $6 \mathrm{~A}$ & 0.01 & Х1397091.19CТ & 3.8 & 0.012 & 10.1 \\
\hline $\mathrm{Na}^{+}: \mathrm{K}^{+} \mathrm{DW}$ & QNa:K.asl-7A & Control & $7 \mathrm{~A}$ & 39.31 & X1193500.27AT & 2.6 & -0.010 & 6.6 \\
\hline $\mathrm{K}^{+}: \mathrm{Na}^{+} \mathrm{DW}$ & QK:Na.asl-6A & Salt & $6 \mathrm{~A}$ & 80.31 & X3023657.26CG & 3.6 & -3.4 & 10.1 \\
\hline
\end{tabular}

$\mathrm{RGR}=$ relative growth rate (days $1-5)$, Growth (1-5)= RGR of plants between 1 and 5 days after salt stress (RGR salt/RGR control) tion on chromosome, most significant marker, LOD score, additive effect and phenotypic variation $\left(R^{2}\right)$ explained by the QTL (\% variation) are shown
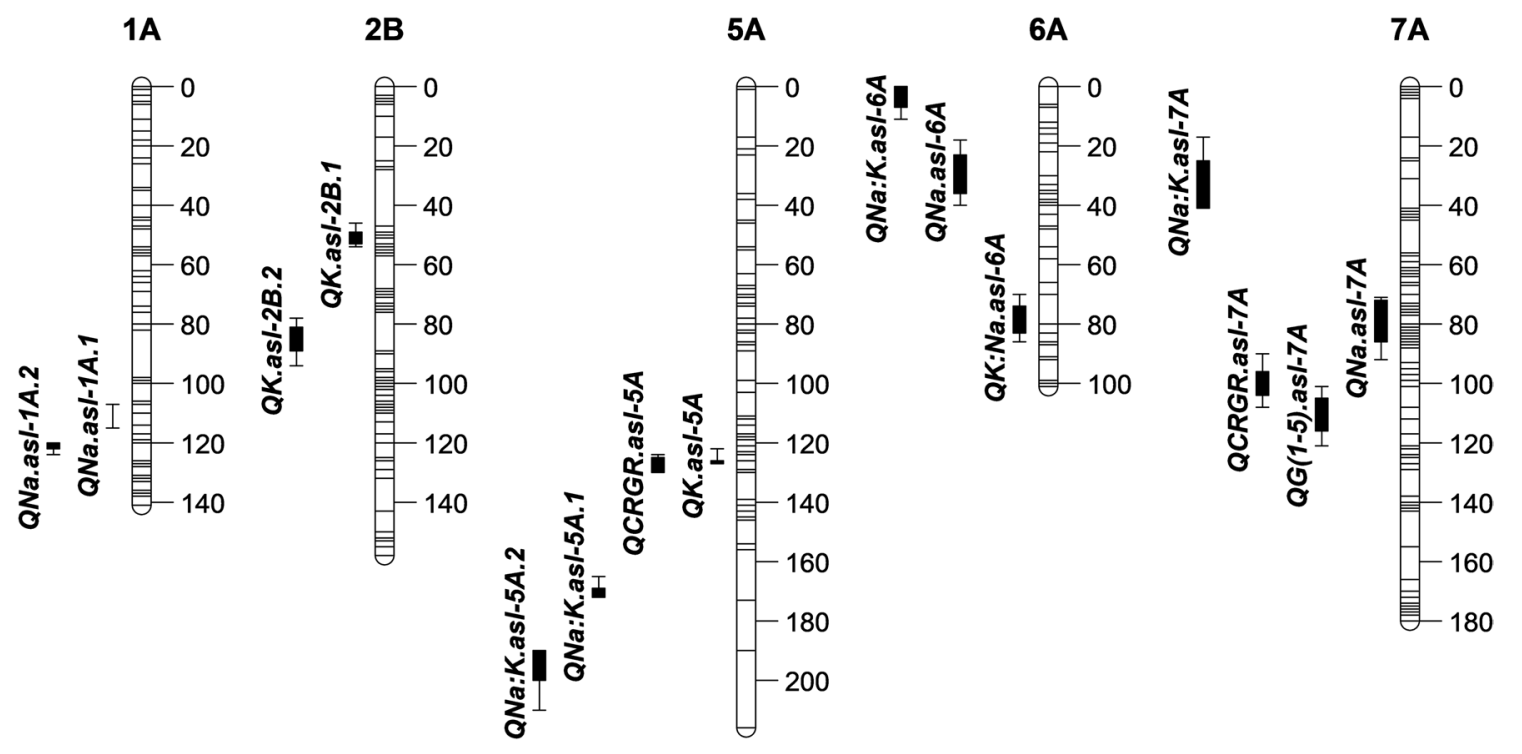

Fig.3 QTL positions for observed traits in the Excalibur $\times$ Kukri DH population under control and salt stress (100 $\mathrm{mM} \mathrm{NaCl}$ for 10 days). The vertical QTL bars represent the 1 and 2 LOD drops from the maximum likelihood value. QTL and their positions are indicated: for Growth $_{(1-5)}\left(Q G_{(1-5)}\right.$.asl-7A), RGR (QRGR.asl-5A and QRGR $-7 A$ ), 4th leaf $\mathrm{Na}^{+}$accumulation ( $\mu \mathrm{mol} / \mathrm{g}$ DW) (QNa.asl-1A.1, QNa.
asl-1A.2, QNa.asl-6A and QNa.asl-7A), $\mathrm{K}^{+}$accumulation ( $\mu \mathrm{mol} / \mathrm{g}$ DW) (QK.asl-2B.1, QK.asl-2B.2 and QK.asl-5A), $\mathrm{Na}^{+}: \mathrm{K}^{+}$(DW) (QNa:K.asl-5A.1, QNa:K.asl-5A.2, QNa:K.asl-6A, QNa:K.asl-7A) and $\mathrm{K}^{+}: \mathrm{Na}^{+}$(DW) (QK:Na.asl-6A). $\mathrm{RGR}=$ relative growth rate (days $1-5)$, Growth $_{(1-5)}=$ RGR of plants between 1 and 5 days after salt stress (RGR salt/RGR control), respectively additive effect (39.7 and 57.4) that was inherited from Excalibur.

For the fourth leaf $\mathrm{Na}^{+}: \mathrm{K}^{+} \mathrm{DW}$ in the control treatment, four QTL were mapped (Table 2): two on chromosome 5A
(QNa:K.asl-5A.1 and QNa:K.asl-5A.2), one on chromosome 6A (QNa:K.asl-6A) and one on chromosome 7A (QNa:K. asl-7A). These had LOD scores ranging from 2.6 to 5.0 and explained between 6.6 and $13.8 \%$ of the phenotypic 
variance. One significant QTL in the salt treatment was detected for $\mathrm{K}^{+}: \mathrm{Na}^{+} \mathrm{DW}$ on chromosome 6A (QK:Na.asl$6 A$ ) with a LOD score of 3.6, explaining $10.1 \%$ of the phenotypic variation. At this QTL, the positive effect (3.4) was inherited from Kukri.

\section{Soil electrical conductivity at the field trial sites}

There was variation in apparent electrical conductivity $\left(\mathrm{EC}_{\mathrm{a}}\right)$ at all field sites (Table 1 and Supplementary Figure 2). At each field location in all years, the mean EM38 values at 0-50 and 0-100 cm were less in the low salt sites compared to the high salt sites (Table 1). Between field locations, Cunderdin 2014 and 2015 high salt sites had the highest $\mathrm{EC}_{\mathrm{a}}$ values at $0-50$ and $0-100 \mathrm{~cm}$ (Table 1). The low salt site at Coomandook in 2015 at $0-50 \mathrm{~cm}$ had a lower $\mathrm{EC}_{\mathrm{a}}$ than the high salt site at the same location but had a higher apparent conductivity than either of the low and high salt sites at Whitwarta in 2014 and the low salt sites at Whitwarta and Cunderdin in 2015 (Table 1).

The soil electrical conductivity $\left(\mathrm{EC}_{1: 5}\right)$ and salinity of the soil solution confirmed the presence of low and high salinity sites at each location (Table 1). Average trial plot values of salinity in the soil solution ranged from 33 to $445 \mathrm{mM}$ at $0-25 \mathrm{~cm}$ and 40 to $646 \mathrm{mM}$ at $25-50 \mathrm{~cm}$ (Table 1 ). Sites with the highest salinity of the soil solution were Cunderdin high salt in 2014 and 2015, Coomandook high salt in 2015 and Whitwarta high salt in 2014. Average trial plot soil $\mathrm{EC}_{1: 5}$ values ranged from $0.03-0.79 \mathrm{dS} / \mathrm{m}$ at $0-25 \mathrm{~cm}$ to $0.06-1.46 \mathrm{dS} / \mathrm{m}$ at $25-50 \mathrm{~cm}$ (Table 1). Locations with the high $\mathrm{EC}_{1: 5}$ were Cunderdin high salt in 2014 and 2015 and Coomandook in 2015 and Whitwarta high salt sites in 2014 and 2015 (Table 1).

\section{Effect of alleles on $\mathrm{Na}^{+}$and $\mathrm{K}^{+}$accumulation}

For the $\mathrm{Na}^{+}$accumulation QTL on chromosome 7A ( $Q N a$. asl-7A), lines with the allele from the $\mathrm{Na}^{+}$exclusion parent (Excalibur) had a decrease in $\mathrm{Na}^{+}$at six out of nine sites, consistent with QTL detected in the glasshouse (Table 3). The most significant amount of $\mathrm{Na}^{+}$exclusion was observed at the low salt site in Cunderdin 2015, where 33.6\% more $\mathrm{Na}^{+}$was excluded compared to the lines carrying the $\mathrm{Na}^{+}$accumulation allele. The difference observed in $\mathrm{Na}^{+}$ exclusion at the other three sites ranged from 0.8 to $13.3 \%$ (Table 3).

Of the four $\mathrm{K}^{+}$accumulation QTL, two (QK.asl-2B.2 and $Q K: N a . a s l-6 A)$ were observed to have the additive effect from the Kukri parent and showed increased accumulation at six out of nine sites (Table 3). For QK.asl-2B.2, lines with the Kukri allele accumulated 13.9 and $7.9 \%$ more $\mathrm{K}^{+}$, respectively, than other lines in the 2014 and 2015 high salt sites at Whitwarta, and lines with this Kukri allele also had
$\mathrm{K}^{+}$accumulation (ranging from 0.8 to $4.7 \%$ ) at four other sites (Table 3). At $Q K$ :Na.asl-6A, the highest $\mathrm{K}^{+}$accumulation effect was observed at the high salt site at Whitwarta in $2014(15.0 \%)$ while at other sites this ranged from 1 to $11.5 \%$. For the other two $\mathrm{K}^{+}$accumulation QTL (QK.asl$2 B .1$ and $Q K$.asl-5A), the beneficial allele was derived from Excalibur. In case of $Q K$.asl-2B.1, the allele of interest enabled lines to accumulate 0.9 to $4.6 \%$ more $\mathrm{K}^{+}$at four trial sites (Table 3). The 5A K $\mathrm{K}^{+}$accumulation QTL (QK.asl-5A) had increased $\mathrm{K}^{+}$accumulation with the allele of interest at the Whitwarta low salt site in 2015 (Table 3).

\section{Effect of alleles on grain yield}

The effect of the alleles of interest on grain yield for all the QTL is summarized in Table 3. For the shoot ionindependent QTL $\left(Q G_{(1-5)}\right.$. asl-7A), the allele for improved growth under salinity treatment is derived from Excalibur and showed yield advantages only at the low and high salt sites at Whitwarta in 2014. However, a number of other QTL had a greater effect on yield at several low and high salt sites (Table 3). For the $\mathrm{Na}^{+}$accumulation QTL on chromosome 7A (QNa.asl-7A), the lines carrying the Excalibur allele increased yield by $12 \%$ at the Whitwarta low salt site in 2015 and by 4 and $6.9 \%$ at the low and high salt sites, respectively, at Whitwarta in 2014 (Table 3). Of the four $\mathrm{K}^{+}$ accumulation QTL (QK.asl-2B.1, QK.asl-2B.2, QK.asl-5A and $Q K$ :Na.asl-6A), QK.asl-2B.2 affected yield at all trial sites, and the other three QTL affected yield advantages at only four sites (Table 3 ).

\section{Screening of cultivars for shoot ion-independent tolerance}

A selection of Australian bread wheat cultivars, as well as one landrace (BH1146), was screened to indicate the prevalence of a marker allele that was associated with the Excalibur like shoot ion-independent tolerance. Genotyping results of 44 accessions showed that the marker allele associated with shoot ion independence was present in five cultivars and the landrace (Supplementary Table 8). Of these accessions, two cultivars (Excalibur and Krichauff) had a mix of plants with $(\mathrm{T}: \mathrm{T})$ sensitive or $(\mathrm{C}: \mathrm{C})$ tolerant alleles.

\section{Predicted genes in QTL regions}

All the marker sequences within the region of 2 LOD drop from the maximum likelihood value of the selected QTL (QG ${ }_{(1-5)}$.asl-7A, QNa.asl-7A, QK.asl-2B.1,QK.asl-2B.2, QK.asl-5A, QK:Na.asl-6A) were used for BLASTn searches to find scaffold sequences from the bread wheat NRGene genome assembly (International Wheat Genome Sequencing Consortium, https://wheat-urgi.versailles.inra.fr/Seq-Repos 


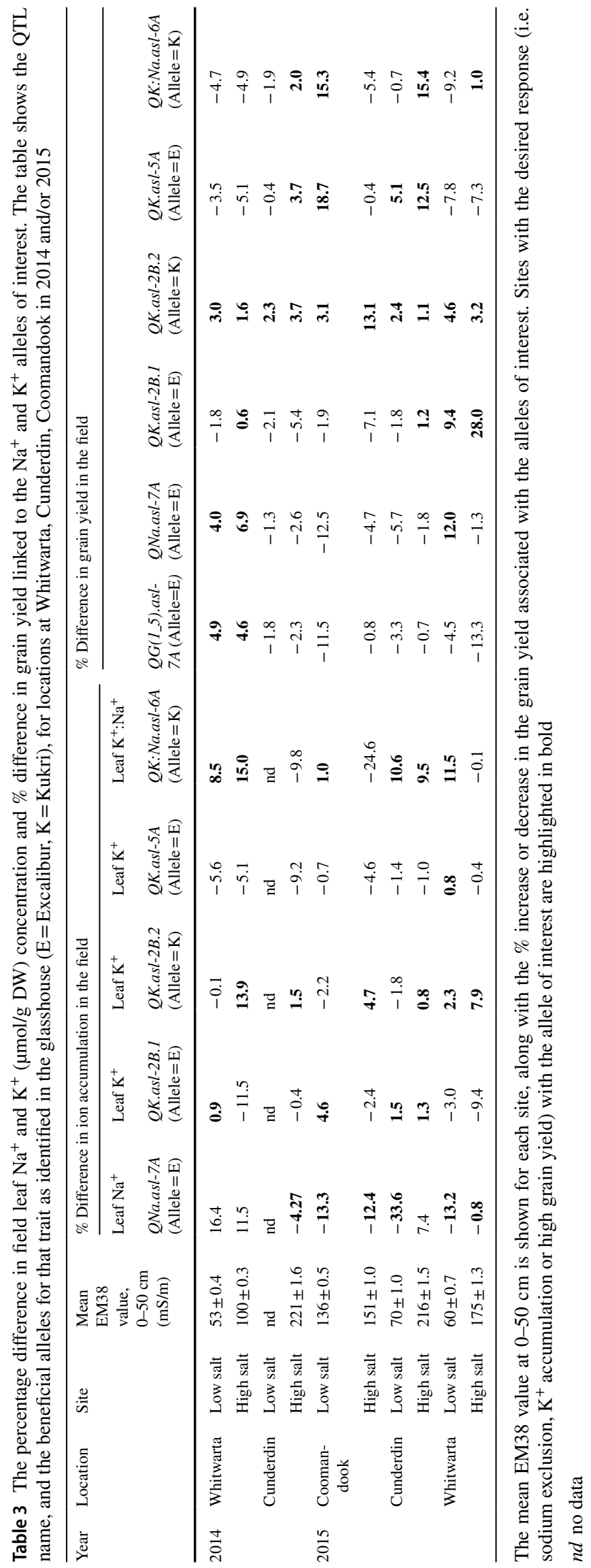


itory/Assemblies). As expected, SNP sequences had their best hits on the corresponding chromosomes, and thus, it was possible to retrieve matching scaffolds underlying the QTL.

The QTL for maintenance of shoot growth under salinity $\left(Q G_{(1-5)}\right.$.asl-7A) were located on five wheat genome scaffolds (scaffold34994-1, scaffold98898, scaffold2159, scaffold75839 and scaffold56294) containing 207 expressed genes (Supplementary Table 9). Within this region, a sodium/hydrogen exchanger 7 (NHX7) also known as salt overly sensitive 1 ( $S O S 1$ ) and a potassium transporter 1 (KUP1) was shortlisted as potential candidate genes based on their role in $\mathrm{Na}^{+}$and $\mathrm{K}^{+}$homoeostasis, respectively (Olias et al. 2009; Sun et al. 2015; Ullah et al. 2016; Zhu 2002, 2003) (Table 4).

For the $\mathrm{Na}^{+}$accumulation QTL (QNa.asl-7A), a total of 12 scaffolds (scaffold9784, scaffold78307, scaffold12617, scaffold18535, scaffold49337, scaffold36269-2, scaffold156548, scaffold107677, scaffold51305, scaffold143236, scaffold18984 and scaffold4982) with 986 expressed genes were retrieved (Supplementary Table 9). A pyrophosphateenergized proton pump $\left(\mathrm{H}^{+}\right.$pyrophosphatase), sodium/ hydrogen exchanger 7 (NHX7) and HKT genes (HKT2;1 and $H K T 2 ; 4)$ were shortlisted as candidate genes based on their role in salt tolerance (Almeida et al. 2013; Gaxiola et al. 2001; Huang et al. 2008; Olias et al. 2009; Ullah et al. 2016; Zhu 2002, 2003) (Table 4).
For the $\mathrm{K}^{+}$accumulation QTL (QK.asl-2B.1), a total of six scaffolds (scaffold32978, scaffold76358-1, scaffold88768, scaffold13132, scaffold 18146 and scaffold60636) with 208 expressed genes were retrieved (Supplementary Table 9). A $\mathrm{K}^{+}$transporter (KUP12) was shortlisted as a candidate gene based on its function (Quintero and Blatt 1997) (Table 4). For the second $\mathrm{K}^{+}$accumulation QTL on chromosome 2B (QK.asl-2B.2), a total of 18 scaffolds with 873 expressed genes were retrieved (Supplementary Table 9) with many potential candidates including $H K T$ genes (HKT1;1 and $H K T 1 ; 4)$, as well as genes encoding a number of $\mathrm{K}^{+}$transporters (including stelar $\mathrm{K}^{+}$outwardly rectifying channel, SKORs), $\mathrm{Cl}^{-}$channels, protein kinases and proline transporters (Table 4$)$.

For $\mathrm{K}^{+}$accumulation QTL (QK.asl-5A), a total of two scaffolds (scaffold45906 and scaffold21633) were identified having 123 expressed genes (Supplementary Table 9) with two obvious candidate genes being a two-pore potassium (TPK) channel and a peptide transporter (Table 4). The TPK channel is known to be involved in $\mathrm{K}^{+}$homoeostasis (Isayenkov et al. 2011), while the peptide transporter 3, also known as AtPTR3, was shown to be involved in seed germination under salt stress (Karim et al. 2005).

For the $\mathrm{K}^{+}: \mathrm{Na}^{+}$QTL (QK:Na.asl-6A), a total of three scaffolds (scaffold32586, scaffold 12078 and scaffold82975) with 188 expressed genes were retrieved. Within this region, there are plasma membrane proton pump ATPase

Table 4 List of potential candidate genes (Gene ID, Gene name) for each QTL, with the respective Munich Information Center for Protein Sequences (MIPS) annotation hit ID and rice annotation hit ID

\begin{tabular}{|c|c|c|c|c|}
\hline QTL & Gene ID & Gene name & MIPS annotation hit ID & Rice annotation hit ID \\
\hline \multirow[t]{2}{*}{$Q G_{(1-5)} \cdot a s l-7 A$} & Traes_7AL_8EB535289 & Sodium/hydrogen exchanger 7 & splQ9LKW9|NHX7_ARATH & LOC_Os12g44360.1 \\
\hline & Traes_7AL_65EAA4F5F & Potassium transporter 1 & AT2G30070.1 & LOC_Os06g45940.2 \\
\hline \multirow[t]{4}{*}{ QNa.asl-7A } & Traes_7AS_0EA301557 & $\begin{array}{l}\mathrm{K}^{+} \text {-insensitive pyrophosphate-ener- } \\
\text { gized proton pump }\end{array}$ & splQ8RCX1|HPPA_THETN & LOC_Os06g08080.1 \\
\hline & Traes_7AL_33B58D8DB & Sodium/hydrogen exchanger 7 & splQ9LKW9|NHX7_ARATH & LOC_Os12g44360.1 \\
\hline & Traes_7AL_0E143E0C2 & Cation transporter HKT1 & sp|A2YGP9|HKT1_ORYSI & LOC_Os06g48810.1 \\
\hline & Traes_7AL_D35672777 & Cation transporter HKT1 & sp|A2YGP9|HKT1_ORYSI & LOC_Os06g48800.1 \\
\hline QK.asl-2B.1 & Traes_2BS_FC456664B & Potassium transporter family protein & AT1G60160.1 & LOC_Os07g32530.1 \\
\hline \multirow[t]{8}{*}{ QK.asl-2B.2 } & Traes_2BL_E48A792E2 & Potassium transporter family protein & AT1G60160.1 & LOC_Os04g32920.4 \\
\hline & Traes_2BL_3198833F4 & Cation transporter HKT1 & splA2YGP9|HKT1_ORYSI & LOC_Os04g51830.1 \\
\hline & Traes_2BL_A34360A6C & Cation transporter HKT1 & sp|A2YGP9|HKT1_ORYSI & LOC_Os04g51820.2 \\
\hline & Traes_2BL_4288159C3 & Cation transporter HKT1 & splA2YGP9|HKT1_ORYSI & LOC_Os04g51830.1 \\
\hline & Traes_2BL_7F4C72451 & Cation transporter HKT1 & sp|A2YGP9|HKT1_ORYSI & LOC_Os04g51830.1 \\
\hline & Traes_2BL_C71ACBCED & Potassium channel SKOR & splQ9M8S6ISKOR_ARATH & LOC_Os04g36740.1 \\
\hline & Traes_2BL_1356B2300 & Chloride channel C & AT5G49890.1 & ChrSy.fgenesh.mRNA.37 \\
\hline & Traes_2BL_8FFBE8AF6 & Proline transporter 1 & AT2G39890.1 & LOC_Os03g44230.1 \\
\hline \multirow[t]{2}{*}{ QK.asl-5A } & Traes_5AL_51E31BF07 & Two-pore potassium channel a & splQ850M0|KCO1_ORYSJ & LOC_Os03g54100.2 \\
\hline & Traes_5AL_ACFA5E386 & Peptide transporter 3 & AT5G46050.1 & LOC_Os11g17970.1 \\
\hline \multirow[t]{2}{*}{ QK:Na.asl-6A } & Traes_6AL_77B5B62A7 & $\mathrm{H}^{+}$-ATPase 6 & AT2G07560.1 & LOC_Os06g08310.1 \\
\hline & Traes_6AL_B830C4A81 & Plasma membrane ATPase 4 & splQ03194|PMA4_NICPL & LOC_Os02g55400.1 \\
\hline
\end{tabular}


$\left(\mathrm{H}^{+}\right.$-ATPase 4 and $\mathrm{H}^{+}$-ATPase 6$)$ which are selected as candidate genes based on their role in salt tolerance (Gévaudant et al. 2007; Morsomme and Boutry 2000) (Supplementary Table 9).

\section{Discussion}

In this study, non-destructive imaging technology was used to map QTL affecting salt tolerance sub-traits in a glasshouse experiment for a DH mapping population of hexaploid wheat. We detected 10 unique QTL under salt and control conditions. These were distributed across five chromosomes: 1A, 2B, 5A, 6A and 7A (Table 2). Some of these QTL were confirmed to have effects in field experiments. At six of nine field trial sites, which varied in their level of salinity stress, alleles for $\mathrm{Na}^{+}$exclusion and/or $\mathrm{K}^{+}$maintenance at three QTL (QNa.asl-7A, QK.asl-2B.2 and QK:Na. asl-6A) were able to exclude more $\mathrm{Na}^{+}$or accumulate more $\mathrm{K}^{+}$(Table 3). At all field sites, the QTL QK.asl-2B.2 had the largest improvement on grain yield. Other QTL also showed yield improvements but only at selected field sites. Some other QTL for $\mathrm{Na}^{+}$exclusion and $\mathrm{K}^{+}$maintenance that were detected in the glasshouse were replicated in the field but did not affect grain yield (Table 3 ).

Four QTL (QK.asl-2B.1, QK.asl-2B.2, QK.asl-5A and $Q K: N a$ asl-6A) were associated with $\mathrm{K}^{+}$accumulation under salinity treatment in the glasshouse. QK.asl-2B.2, the second most significant QTL detected for leaf $\mathrm{K}^{+}$accumulation in the glasshouse, was validated in both low and high salinity field sites (Table 3). This QTL was consistently associated with grain yield effects of $1-13 \%$, averaging $4 \%$ (Table 3). Maintenance of high levels of $\mathrm{K}^{+}$in a plant cell under salinity stress, which has previously been reported to be an important sub-trait of salt tolerance (Cuin et al. 2008, 2009; Shabala 2013), vital metabolic processes such as protein synthesis (Blaha et al. 2000; Wyn Jones et al. 1979), key enzyme activity (Bhandal and Malik 1988) and signalling mechanisms (Shabala 2017).

Among 873 genes within the interval of QK.asl-2B.2, there are two predicted $H K T$ genes $(H K T 1 ; 1$ and $H K T 1 ; 4)$ (Huang et al. 2008), several predicted genes that encode $\mathrm{K}^{+}$transporters (including stelar $\mathrm{K}^{+}$outwardly rectifying channel, SKORs), $\mathrm{Cl}^{-}$channels, protein kinases and proline transporters (Table 4). TmHKTl;4 (Naxl) have been shown to improve $\mathrm{Na}^{+}$exclusion (and $\mathrm{K}^{+}$retention) when introgressed into durum wheat (James et al. 2006, 2012) but did not improve yield in the field (James et al. 2012). When TmHKT1;4 was introgressed into bread wheat, a similar ionic phenotype was observed (James et al. 2011). Enhanced control over $\mathrm{Na}^{+}$and $\mathrm{K}^{+}$transport in bread wheat would allow for better maintenance of high levels of $\mathrm{K}^{+}$in a plant under salinity stress and may be associated with the QK.asl-2B.2 detected in this study.

Two other QTL that were detected for $\mathrm{K}^{+}$accumulation (QK.asl-2B.1; QK.asl-5A) in glasshouse experiments were not validated at field sites. Each of these was detected in a region with a known developmental gene: the photoperiodinsensitive gene $P p d-B 1$ (QK.asl-2B.1), or the vernalization gene Vrn-Al (QK.asl-5A). In other studies, QTL for multiple traits including tiller number, seedling biomass, chlorophyll content, plant height and yield have been detected in the same genetic region as Vrn-Al, in wheat grown in saline and/or non-saline treatments (De León et al. 2011; Genc et al. 2010; Hill et al. 2015; Kato et al. 2000; Kumar et al. 2007).

Although QK.asl-5A seems to coincide with $V r n-A 1$, it was detected in salt-stressed treatments but not in the control treatment (Table 2). This indicates that genes other than $V r n-A 1$ may be responsible for the QKasl-5A effect. These may include genes that are orthologous to Arabidopsis genes that encode an element of the two-pore potassium (TPK) channel (Hartley and Maathuis 2016; Isayenkov et al. 2011) or the peptide transporter 3 (AtPTR3) (Table 4). When expressed ubiquitously, the Arabidopsis TPKI affects salt tolerance (Latz et al. 2013), stomatal closure (Gobert et al. 2007; Ward and Schroeder 1994) and general $\mathrm{K}^{+}$homoeostasis (Gobert et al. 2007; Hamamoto et al. 2008). The other gene, an ortholog of AtPTR3, belongs to the nitrate excretion transporter (NAXT) sub-family of the nitrate transporter 1/ peptide transporter (NRT1/PTR) family (NPF) (Léran et al. 2014; Li et al. 2017; Segonzac et al. 2007; Tsay et al. 2007). In Arabidopsis, around 50 putative NRT1/PTR-type transporters have been identified (Karim et al. 2005), some of which have been implicated in salt tolerance mechanisms (Karim et al. 2005; Li et al. 2017). To determine whether the $\mathrm{K}^{+}$QTL mapped in this region is due to $V r n-A l$ itself or some other gene(s), more lines with recombination events in this region would need to be phenotyped and genotyped. Previously, this approach was used to separate the effect of the Nax3 (HVP10) gene from the flowering time gene $H v F T$ in a barley mapping population (Shavrukov et al. 2013).

A QTL on chromosome 7A for leaf $\mathrm{Na}^{+}$exclusion (QNa.asl-7A) (Table 2) was detected under $100 \mathrm{mM}$ salt stress in the glasshouse. This leaf $\mathrm{Na}^{+}$exclusion QTL was verified in most field sites, with lines carrying the same marker alleles as Excalibur having up to $34 \%$ lower leaf $\mathrm{Na}^{+}$than those with Kukri alleles (Table 3). This QTL is in the same region as a leaf $\mathrm{Na}^{+}$exclusion QTL previously detected on chromosome $7 \mathrm{~A}$ in a Cranbrook $\times$ Halberd population and Excalibur $\times$ Kukri DH (Edwards 2012; Shavrukov et al. 2011). Within this QTL interval, several salt tolerance genes such as a proton pumping pyrophosphate $\left(\mathrm{H}^{+}\right.$-pyrophosphatase), sodium/hydrogen exchanger 7 (NHX7) and HKT genes (HKT2;1 and HKT2;4) have been 
found (Table 4). The $\mathrm{H}^{+}$-pyrophosphatase is the closest of these genes to the peak of the QTL. Enhanced expression of $\mathrm{H}^{+}$-pyrophosphatase (Gaxiola et al. 2001; Park et al. 2005; Pasapula et al. 2011; Schilling et al. 2014), particularly in conjunction with enhanced sodium/hydrogen exchanger gene expression (Bhaskaran and Savithramma 2011; Gaxiola et al. 1999; Zhao et al. 2006), such as NHX7 which is also within this QTL, has been shown to enhance salinity tolerance. The HKT genes are the most distant of these four genes from the peak; however, previous studies (Ariyarathna et al. 2014, 2016; Huang et al. 2008) have also reported the presence of these genes in the same region as QTL for leaf $\mathrm{Na}^{+}$concentration and yield measurements under different saline environments (Genc et al. 2010, 2013). Identification of leaf $\mathrm{Na}^{+}$exclusion QTL in current and previous studies (Edwards 2012; Genc et al. 2010, 2013; Shavrukov et al. 2011) on chromosome 7A and the presence of $H K T$ genes (HKT2; 1 and HKT2;4) in this region suggest the importance of this locus in salt tolerance. TaHKT2;1 has been described as a $\mathrm{Na}^{+}$-coupled $\mathrm{K}^{+}$transporter protein (Gassmann and Schroeder 1994; Sato et al. 2014; Schachtman and Schroeder 1994) which is involved in balancing $\mathrm{K}^{+}: \mathrm{Na}^{+}$ratio in the plant. Care is needed in interpreting these results as the DAWN and POTAGE bioinformatics tools that were used here to identify candidate genes, only search databases that contain wheat genes expressed under control treatments. Any genes involved in salinity tolerance that are expressed only at low levels in non-salt-stressed plant would not be represented in these databases. With transcript analysis of salt-stressed wheat, it might be possible to identify additional candidate genes within this region which have not been captured by the current bioinformatics analysis. Additionally, fine mapping of the region will help reduce the number of genes.

Very few studies have investigated the impact of $\mathrm{Na}^{+}$ exclusion alleles on yield in the field. Despite the $Q N a$. asl-7A allele being associated with leaf $\mathrm{Na}^{+}$exclusion, this allele was not correlated with yield improvement in lowto-moderate saline sites (Table 3). The lack of a positive correlation between leaf $\mathrm{Na}^{+}$exclusion and yield in bread wheat has been noted in other studies (Genc et al. 2013). It is apparent that improving salinity tolerance of bread wheat across a range of salinity environments is not simply a matter of enhancing leaf $\mathrm{Na}^{+}$exclusion in bread wheat.

$\mathrm{Na}^{+}$exclusion has been found to improve salinity tolerance and yield performance under increasing salinity for the high shoot $\mathrm{Na}^{+}$accumulating crops durum wheat (James et al. 2012; Munns et al. 2012) and barley (Tilbrook et al. 2017). A derivative of the durum cultivar Tamaroi containing the Nax2 locus (TmHKT1;5-A) had 25\% higher yield in a highly saline area $\left(\mathrm{EC}_{\mathrm{e}}=14.8 \mathrm{dS} / \mathrm{m}\right)$ compared to Tamaroi without the locus (Munns et al. 2012). While leaf $\mathrm{Na}^{+}$exclusion did not improve the yield of bread wheat in our study, the previous success with $\mathrm{Na}^{+}$exclusion in durum wheat in more saline environments indicates that it can improve yield in certain crops/cultivars under specific environments. It is conceivable that, as bread wheat is already a good shoot $\mathrm{Na}^{+}$ excluder, enhancing this capability in bread wheat is not necessarily going to result in large improvements in salinity tolerance. Shoot $\mathrm{Na}^{+}$exclusion may therefore be a more important mechanism to improve the yield stability of crop species that accumulate high concentrations of shoot $\mathrm{Na}^{+}$.

A novel QTL for shoot ion-independent tolerance was detected on chromosome $7 \mathrm{~A}\left(Q G_{(1-5)}\right.$. asl-7A). To date there is no published QTL about the presence of shoot tolerance mechanisms not related to shoot ion concentration in wheat; however, QTL for growth traits have recently been detected in rice on chromosomes 1, 3, 5, 8 and 11 (Al-Tamimi et al. 2016; Campbell et al. 2015). A QTL for osmotic regulation has previously been mapped on chromosome 7A (Morgan and Tan 1996), but not in the same region as the shoot ionindependent tolerance QTL reported here. Analysis of the shoot ion-independent QTL by POTAGE and DAWN identified 207 genes within the region. One of these genes encodes $\mathrm{a} \mathrm{K}^{+}$transporter (KUPl) which is important in maintaining potassium homoeostasis (Hu et al. 2005; Maathuis and Amtmann 1999; Sun et al. 2015), while the second one (NHX7) is involved in $\mathrm{Na}^{+}$transport (Olias et al. 2009; Ullah et al. 2016; Zhu 2002, 2003). Further fine mapping is required to reduce the number of candidate genes linked to the phenotype.

$Q G_{(1-5)}$.asl-7A had no large effect on yield in the field, despite having a significant effect in the glasshouse $\left(\mathrm{LOD}=5\right.$, phenotypic variation $\left.\left(R^{2}\right)=14.1 \%\right)$. Only at Whitwarta (low and high salt) in 2014 was there any yield improvement (Table 3). The lack of yield improvement at multiple sites may be due to the complex nature of the shoot ion-independent tolerance mechanism and the influence of other multiple environmental and biotic factors. In addition to salinity, plants in a saline field are also affected by other abiotic stresses, with the most common of these being drought and waterlogging (Colmer et al. 2005; Genc et al. 2013; Mittler 2006; Munns 2002; Munns et al. 2016; Tester and Davenport 2003). Concurrent occurrence of two or more stresses is considered more detrimental to plant performance than an individual stress alone (Barrett-Lennard 2003; Mittler 2006; Pandey et al. 2015). Some of our trial sites were exposed to harsher environmental conditions at the start of the growing season (such as waterlogging and low water availability), while others experienced low rainfall towards the end of the growing season (Supplementary Table 2 and Supplementary Figure 1).

A direct measurement of shoot ion-independent tolerance in the field is lacking to confirm the phenotype observed in the glasshouse. Alleles for early growth response to salinity stress may improve biomass 
production during seedling establishment. Technology to measure plant phenotypes, such as biomass, water use, shoot health (senescence) and canopy temperature, late in the growing season is now possible using platforms, such as drones, phenotowers and phenomobiles fitted with a selection of RGB, LiDAR and multispectral cameras (Araus and Cairns 2014; Deery et al. 2014, 2016; Furbank and Tester 2011; Großkinsky et al. 2015; Losos et al. 2013; Rascher et al. 2011). However, robust non-destructive phenotyping techniques to accurately measure early plant growth over time in the field are still in their infancy. As new technologies become available, it will be possible to measure shoot ion-independent phenotypes in young plants in the field to determine whether glasshouse shoot ion-independent tolerance can be translated in the field.

We cannot rule out shoot ion-independent tolerance as an important trait. When a marker for $Q G_{(1-5)}$. $a s l-7 A$ was assayed on 44 varieties of bread wheat and one landrace, the tolerance-associated allele present in Excalibur-198 was detected in Axe, BH1146 (a landrace), Estoc and Halberd (Supplementary Table 8). The allele was also present in the heterogeneous Excalibur and Krichauff cultivars; plants of either of these cultivars could have the Excalibur-198 or the Kukri allele. Of these six accessions, four (Krichauff, Excalibur, Halberd and BH1146) have been reported as having salinity tolerance (Genc et al. 2007; Khokhar et al. 2017; Takahashi et al. 2015; Zhu et al. 2016). Future work should focus on identification of haplotypes and their link to salinity tolerance in this QTL locus. It is possible that shoot ion-independent tolerance will have an improvement on crop growth when combined with other salinity tolerance sub-traits, such as leaf $\mathrm{Na}^{+}$exclusion and $\mathrm{K}^{+}$maintenance (Rajendran et al. 2009; Tilbrook et al. 2017). The development of crops with improved yield in hostile environments will require the pyramiding of multiple traits including, but not exclusive to, tolerance to boron, drought, heat, frost, waterlogging, $\mathrm{pH}$, nematodes and multiple diseases and pathogens, as well as optimizing phenology while maintaining grain yield and quality.

In summary, a number of QTL for salinity tolerance mechanisms identified in the glasshouse were validated in the field. Promisingly, several of these loci were also linked to improved yield in up to nine field sites, across multiple years. QTL for shoot ion-independent tolerance were also detected for the first time in glasshouse grown bread wheat. Future work should focus on developing robust measurements for measuring shoot ion-independent tolerance in the field and positional cloning of the gene(s) responsible for all the identified QTL.

Author contribution statement MA. performed genotyping, QTL analysis and experiments, R.S. and S.R conducted field trials and performed data analysis, C.B, K.D. and H.R. completed experimental design and statistical analysis, R.S. J.T, E.B-L, L.S, C.T and S.R. performed glasshouse and field experiments. A.G contributed to QTL analysis, D.M assisted in map construction, D.F and A.P contributed to genetic analysis and supervision and B.B, M.G, M.T and S.R conceived the study. All authors contributed to writing and reviewing the manuscript.

Acknowledgements This project was funded by the Grains Research and Development Corporation (GRDC): Project UA00118 to MT, SJR; UA00145 to SJR, BB, MG and EGB-L; and UA00159 to SJR and MG. We also acknowledge the South Australian growers and Cunderdin Agricultural College, Western Australia who provided land for field trials, South Australian Research and Development Institute (SARDI) new varieties agronomy team, Kalyx Australia and Mr. David Farleigh (DPIRD), Mr. Rob Jeffrey (UWA), Dr. Louis Mayer (UWA), Dr. Victoria Marchesini (UWA), Dr. Christa Niemietz (UofA), Dr. Jiaen Qiu (UofA) and Mr. Nigel Schilling (UofA) for field trial assistance, and The Plant Accelerator ${ }^{\circledR}$ staff who assisted with the glasshouse experiments. The Plant Accelerator ${ }^{\circledR}$, Australian Plant Phenomics Facility, is funded under the National Collaborative Research Infrastructure Strategy (NCRIS). The bread wheat genome assembly was accessed through the International Wheat Genome Sequencing Consortium at https://wheat-urgi.versailles.inra.fr/Seq-Repository/Assemblies. MAA thanks the University of Adelaide for Adelaide Scholarships International (ASI) and the Australian Centre for Plant Functional Genomics for his $\mathrm{PhD}$ stipend, also acknowledged the financial support from the Australian Society of Plant Scientists (ASPS), the Crop Science Society of South Australia Incorporated and the Plant Nutrition Trust to attend conferences. MT thanks King Abdullah University of Science and Technology (KAUST) for financial support.

\section{Compliance with ethical standards}

Conflict of interest The authors declare that they have no conflict of interest.

Open Access This article is distributed under the terms of the Creative Commons Attribution 4.0 International License (http://creativeco mmons.org/licenses/by/4.0/), which permits unrestricted use, distribution, and reproduction in any medium, provided you give appropriate credit to the original author(s) and the source, provide a link to the Creative Commons license, and indicate if changes were made.

\section{References}

Allen AM, Barker GLA, Wilkinson P, Burridge A, Winfield M, Coghill J, Uauy C, Griffiths S, Jack P, Berry S, Werner P, Melichar JPE, McDougall J, Gwilliam R, Robinson P, Edwards KJ (2013) Discovery and development of exome-based, co-dominant single nucleotide polymorphism markers in hexaploid wheat (Triticum aestivum L.). Plant Biotechnol J 11(3):279-295

Almeida P, Katschnig D, de Boer AH (2013) HKT transporters-state of the art. Int J Mol Sci 14:20359-20385

Al-Tamimi N, Brien C, Oakey H, Berger B, Saade S, Ho YS, Schmöckel SM, Tester M, Negrão S (2016) Salinity tolerance 
loci revealed in rice using high-throughput non-invasive phenotyping. Nat Commun 7:13342

Araus JL, Cairns JE (2014) Field high-throughput phenotyping: the new crop breeding frontier. Trends Plant Sci 19:52-61

Ariyarathna HCK, Ul-Haq T, Colmer TD, Francki MG (2014) Characterization of the multigene family TaHKT 2; 1 in bread wheat and the role of gene members in plant $\mathrm{Na}^{+}$and $\mathrm{K}^{+}$status. BMC Plant Biol 14:159

Ariyarathna HCK, Oldach KH, Francki MG (2016) A comparative gene analysis with rice identified orthologous group II $H K T$ genes and their association with $\mathrm{Na}^{+}$concentration in bread wheat. BMC Plant Biol 16:21

Atieno J, Li Y, Langridge P, Dowling K, Brien C, Berger B, Varshney RK, Sutton T (2017) Exploring genetic variation for salinity tolerance in chickpea using image-based phenotyping. Sci Rep $7: 1300$

Barrett-Lennard E (2003) The interaction between waterlogging and salinity in higher plants: causes, consequences and implications. Plant Soil 253:35-54

Bhandal IS, Malik C (1988) Potassium estimation, uptake, and its role in the physiology and metabolism of flowering plants. Int Rev Cytol 110:205

Bhaskaran S, Savithramma D (2011) Co-expression of Pennisetum glaucum vacuolar $\mathrm{Na}^{+} / \mathrm{H}^{+}$antiporter and Arabidopsis $\mathrm{H}^{+}$-pyrophosphatase enhances salt tolerance in transgenic tomato. J Exp Bot 62:5561-5570

Blaha G, Stelzl U, Spahn CM, Agrawal RK, Frank J, Nierhaus KH (2000) Preparation of functional ribosomal complexes and effect of buffer conditions on tRNA positions observed by cryoelectron microscopy. Methods Enzymol 317:292-309

Brien C (2015a) asremlPlus: a collection of functions to augment the use of asreml in fitting mixed models. $\mathrm{R}$ package version 2.0-2. https://CRAN.R-project.org/package=asremlPlus. Accessed 4 Nov 42015

Brien C (2015b) Dae: functions useful in the design and ANOVA of experiments. R package version 2.7-6. https://CRAN.R-proje ct.org/package $=$ dae. Accessed 4 Nov 2015

Brien CJ, Berger B, Rabie H, Tester M (2013) Accounting for variation in designing greenhouse experiments with special reference to greenhouses containing plants on conveyor systems. Plant Methods 9:5

Butler D, Cullis B, Gilmour A, Gogel B (2009) Analysis of mixed models for S language environments: ASReml-R reference manual. Queensland DPI, Brisbane

Campbell MT, Knecht AC, Berger B, Brien CJ, Wang D, Walia H (2015) Integrating image-based phenomics and association analysis to dissect the genetic architecture of temporal salinity responses in rice. Plant Physiol 168:1476-1489

Cavanagh CR, Chao S, Wang S, Huang BE, Stephen S, Kiani S, Forrest K, Saintenac C, Brown-Guedira GL, Akhunova A (2013) Genome-wide comparative diversity uncovers multiple targets of selection for improvement in hexaploid wheat landraces and cultivars. Proc Natl Acad Sci USA 110:8057-8062

Chen Z, Newman I, Zhou M, Mendham N, Zhang G, Shabala S (2005) Screening plants for salt tolerance by measuring $\mathrm{K}^{+}$ flux: a case study for barley. Plant Cell Environ 28:1230-1246

Choulet F, Alberti A, Theil S, Glover N, Barbe V, Daron J, Pingault L, Sourdille P, Couloux A, Paux E (2014) Structural and functional partitioning of bread wheat chromosome $3 \mathrm{~B}$. Science 345:1249721

Churchill GA, Doerge RW (1994) Empirical threshold values for quantitative trait mapping. Genetics 138:963-971

Colmer T, Munns R, Flowers T (2005) Improving salt tolerance of wheat and barley: future prospects. Aust J Exp Agric $45: 1425-1443$
Coombes NE (2009) DiGGer: design search tool in R. http://www. austatgen.org/files/software/downloads/. Accessed 6 June 2011

Cuin TA, Betts SA, Chalmandrier R, Shabala S (2008) A root's ability to retain $\mathrm{K}^{+}$correlates with salt tolerance in wheat. J Exp Bot 59:2697-2706

Cuin TA, Tian Y, Betts SA, Chalmandrier R, Shabala S (2009) Ionic relations and osmotic adjustment in durum and bread wheat under saline conditions. Funct Plant Biol 36:1110-1119

De León JLD, Escoppinichi R, Geraldo N, Castellanos T, Mujeeb-Kazi A, Röder MS (2011) Quantitative trait loci associated with salinity tolerance in field grown bread wheat. Euphytica 181:371-383

Deery D, Jimenez-Berni J, Jones H, Sirault X, Furbank R (2014) Proximal remote sensing buggies and potential applications for fieldbased phenotyping. Agronomy 4:349-379

Deery DM, Rebetzke GJ, Jimenez-Berni JA, James RA, Condon AG, Bovill WD, Hutchinson P, Scarrow J, Davy R, Furbank RT (2016) Methodology for high-throughput field phenotyping of canopy temperature using airborne thermography. Front Plant Sci 7:1808

Edwards J (2012) A genetic analysis of drought related traits in hexaploid wheat. Dissertation, The University of Adelaide, Australia

Edwards D, Wilcox S, Barrero RA, Fleury D, Cavanagh CR, Forrest KL, Hayden MJ, Moolhuijzen P, Keeble-Gagnère G, Bellgard MI (2012) Bread matters: a national initiative to profile the genetic diversity of Australian wheat. Plant Biotechnol J 10:703-708

FAO (2017) FAO soils portal. http://www.fao.org/soils-portal/soilmanagement/management-of-some-problem-soils/salt-affec ted-soils/more-information-on-salt-affected-soils/en/. Accessed 23 Aug 2017

Flowers T (2004) Improving crop salt tolerance. J Exp Bot 55:307-319

Flowers TJ, Colmer TD (2008) Salinity tolerance in halophytes. New Phytol 179:945-963

Flowers TJ, Garcia A, Koyama M, Yeo AR (1997) Breeding for salt tolerance in crop plants-the role of molecular biology. Acta Physiol Plant 19:427-433

Fricke W, Peters WS (2002) The biophysics of leaf growth in salt-stressed barley. A study at the cell level. Plant Physiol 129:374-388

Furbank RT, Tester M (2011) Phenomics-technologies to relieve the phenotyping bottleneck. Trends Plant Sci 16:635-644

Gassmann W, Schroeder JI (1994) Inward-rectifying $\mathrm{K}^{+}$channels in root hairs of wheat (a mechanism for aluminum-sensitive lowaffinity $\mathrm{K}^{+}$uptake and membrane potential control). Plant Physiol 105:1399-1408

Gaxiola RA, Rao R, Sherman A, Grisafi P, Alper SL, Fink GR (1999) The Arabidopsis thaliana proton transporters, AtNhx1 and Avp1, can function in cation detoxification in yeast. Proc Natl Acad Sci USA 96:1480-1485

Gaxiola RA, Li J, Undurraga S, Dang LM, Allen GJ, Alper SL, Fink GR (2001) Drought-and salt-tolerant plants result from overexpression of the AVP1 $\mathrm{H}^{+}$-pump. Proc Natl Acad Sci USA 98:11444-11449

Genc Y, Mcdonald GK, Tester M (2007) Reassessment of tissue $\mathrm{Na}^{+}$ concentration as a criterion for salinity tolerance in bread wheat. Plant, Cell Environ 30:1486-1498

Genc Y, Oldach K, Verbyla A, Lott G, Hassan M, Tester M, Wallwork H, McDonald G (2010) Sodium exclusion QTL associated with improved seedling growth in bread wheat under salinity stress. Theor Appl Genet 121:877-894

Genc Y, Oldach K, Gogel B, Wallwork H, McDonald GK, Smith AB (2013) Quantitative trait loci for agronomic and physiological traits for a bread wheat population grown in environments with a range of salinity levels. Mol Breed 32:39-59

Gévaudant F, Duby G, von Stedingk E, Zhao R, Morsomme P, Boutry M (2007) Expression of a constitutively activated plasma 
membrane $\mathrm{H}^{+}$-ATPase alters plant development and increases salt tolerance. Plant Physiol 144:1763-1776

Gilliham M, Able JA, Roy SJ (2017) Translating knowledge in abiotic stress tolerance to breeding programs. Plant J 90:898-917

Gobert A, Isayenkov S, Voelker C, Czempinski K, Maathuis FJ (2007) The two-pore channel TPKl gene encodes the vacuolar $\mathrm{K}^{+}$conductance and plays a role in $\mathrm{K}^{+}$homeostasis. Proc Natl Acad Sci USA 104:10726-10731

Golzarian MR, Frick RA, Rajendran K, Berger B, Roy S, Tester M, Lun DS (2011) Accurate inference of shoot biomass from highthroughput images of cereal plants. Plant Methods 7:2

Großkinsky DK, Svensgaard J, Christensen S, Roitsch T (2015) Plant phenomics and the need for physiological phenotyping across scales to narrow the genotype-to-phenotype knowledge gap. J Exp Bot 66:5429-5440

Hamamoto S, Marui J, Matsuoka K, Higashi K, Igarashi K, Nakagawa T, Kuroda T, Mori Y, Murata Y, Nakanishi Y (2008) Characterization of a tobacco TPK-type $\mathrm{K}^{+}$channel as a novel tonoplast $\mathrm{K}^{+}$channel using yeast tonoplasts. J Biol Chem 283:1911-1920

Hartley TN, Maathuis FJ (2016) Allelic variation in the vacuolar TPK1 channel affects its calcium dependence and may impact on stomatal conductance. FEBS Lett 590:110-117

Hasegawa PM (2013) Sodium $\left(\mathrm{Na}^{+}\right)$homeostasis and salt tolerance of plants. Environ Exp Bot 92:19-31

Hasegawa PM, Bressan RA, Zhu J-K, Bohnert HJ (2000) Plant cellular and molecular responses to high salinity. Annu Rev Plant Biol $51: 463-499$

Hill CB, Taylor JD, Edwards J, Mather D, Bacic A, Langridge P, Roessner U (2013) Whole-genome mapping of agronomic and metabolic traits to identify novel quantitative trait loci in bread wheat grown in a water-limited environment. Plant Physiol 162:1266-1281

Hill CB, Taylor JD, Edwards J, Mather D, Langridge P, Bacic A, Roessner U (2015) Detection of QTL for metabolic and agronomic traits in wheat with adjustments for variation at genetic loci that affect plant phenology. Plant Sci 233:143-154

Hu Y, Fricke W, Schmidhalter U (2005) Salinity and the growth of nonhalophytic grass leaves: the role of mineral nutrient distribution. Funct Plant Biol 32:973-985

Huang S, Spielmeyer W, Lagudah ES, Munns R (2008) Comparative mapping of HKT genes in wheat, barley, and rice, key determinants of $\mathrm{Na}^{+}$transport, and salt tolerance. J Exp Bot 59:927-937

International Wheat Genome Sequencing Consortium (2014) A chromosome-based draft sequence of the hexaploid bread wheat (Triticum aestivum) genome. Science 345:1251788

Isayenkov S, Isner J-C, Maathuis FJ (2011) Rice two-pore $\mathrm{K}^{+}$channels are expressed in different types of vacuoles. Plant Cell 23:756-768

Izanloo A, Condon AG, Langridge P, Tester M, Schnurbusch T (2008) Different mechanisms of adaptation to cyclic water stress in two South Australian bread wheat cultivars. J Exp Bot 59:3327-3346

James RA, Davenport RJ, Munns R (2006) Physiological characterization of two genes for $\mathrm{Na}^{+}$exclusion in durum wheat, Naxl and Nax2. Plant Physiol 142:1537-1547

James RA, Blake C, Byrt CS, Munns R (2011) Major genes for $\mathrm{Na}^{+}$ exclusion, Naxl and Nax2 (wheat HKT1; 4 and HKT1; 5), decrease $\mathrm{Na}^{+}$accumulation in bread wheat leaves under saline and waterlogged conditions. J Exp Bot 62:2939-2947

James RA, Blake C, Zwart AB, Hare RA, Rathjen AJ, Munns R (2012) Impact of ancestral wheat sodium exclusion genes Naxl and Nax 2 on grain yield of durum wheat on saline soils. Funct Plant Biol 39:609-618

Jayatilake DV, Tucker EJ, Bariana H, Kuchel H, Edwards J, McKay AC, Chalmers K, Mather DE (2013) Genetic mapping and marker development for resistance of wheat against the root lesion nematode Pratylenchus neglectus. BMC Plant Biol 13:230
Karim S, Lundh D, Holmström K-O, Mandal A, Pirhonen M (2005) Structural and functional characterization of AtPTR3, a stressinduced peptide transporter of Arabidopsis. J Mol Model 11:226-236

Kato K, Miura H, Sawada S (2000) Mapping QTLs controlling grain yield and its components on chromosome $5 \mathrm{~A}$ of wheat. Theor Appl Genet 101:1114-1121

Khokhar JS, Sareen S, Tyagi BS, Singh G, Chowdhury AK, Dhar T, Singh V, King IP, Young SD, Broadley MR (2017) Characterising variation in wheat traits under hostile soil conditions in India. PLoS ONE 12:e179208

Kosambi D (1943) The estimation of map distances from recombination values. Ann Eugen 12:172-175

Kumar N, Kulwal P, Balyan H, Gupta P (2007) QTL mapping for yield and yield contributing traits in two mapping populations of bread wheat. Mol Breed 19:163-177

Latz A, Mehlmer N, Zapf S, Mueller TD, Wurzinger B, Pfister B, Csaszar E, Hedrich R, Teige M, Becker D (2013) Salt stress triggers phosphorylation of the Arabidopsis vacuolar $\mathrm{K}^{+}$channel TPK1 by calcium-dependent protein kinases (CDPKs). Mol Plant 6:1274-1289

Léran S, Varala K, Boyer J-C, Chiurazzi M, Crawford N, Daniel-Vedele F, David L, Dickstein R, Fernandez E, Forde B (2014) A unified nomenclature of NITRATE TRANSPORTER 1/PEPTIDE TRANSPORTER family members in plants. Trends Plant Sci 19:5-9

Li B, Qiu J, Jayakannan M, Xu B, Li Y, Mayo GM, Tester M, Gilliham M, Roy SJ (2017) AtNPF2. 5 modulates chloride $\left(\mathrm{Cl}^{-}\right)$efflux from roots of Arabidopsis thaliana. Front Plant Sci 7:2013

Losos JB, Arnold SJ, Bejerano G, Brodie E III, Hibbett D, Hoekstra HE, Mindell DP, Monteiro A, Moritz C, Orr HA (2013) Evolutionary biology for the 21st century. PLoS Biol 11:e1001466

Maathuis FJ, Amtmann A (1999) $\mathrm{K}^{+}$nutrition and $\mathrm{Na}^{+}$toxicity: the basis of cellular $\mathrm{K}^{+} / \mathrm{Na}^{+}$ratios. Ann Bot 84:123-133

Manly KF, Cudmore RH Jr, Meer JM (2001) Map Manager QTX, cross-platform software for genetic mapping. Mamm Genome 12:930-932

Mittler R (2006) Abiotic stress, the field environment and stress combination. Trends Plant Sci 11:15-19

Morgan J, Tan M (1996) Chromosomal location of a wheat osmoregulation gene using RFLP analysis. Funct Plant Biol 23:803-806

Morsomme P, Boutry M (2000) The plant plasma membrane $\mathrm{H}^{+}$-ATPase: structure, function and regulation. Biochim Biophys Acta (BBA) Biomembr 1465:1-16

Munns R (2002) Comparative physiology of salt and water stress. Plant Cell Environ 25:239-250

Munns R, Gilliham M (2015) Salinity tolerance of crops-what is the cost? New Phytol 208:668-673

Munns R, Tester M (2008) Mechanisms of salinity tolerance. Annu Rev Plant Biol 59:651-681

Munns R, James RA, Xu B, Athman A, Conn SJ, Jordans C, Byrt CS, Hare RA, Tyerman SD, Tester M (2012) Wheat grain yield on saline soils is improved by an ancestral $\mathrm{Na}^{+}$transporter gene. Nat Biotechnol 30:360-364

Munns R, James RA, Gilliham M, Flowers TJ, Colmer TD (2016) Tissue tolerance: an essential but elusive trait for salt-tolerant crops. Funct Plant Biol 43:1103-1113

Olias R, Eljakaoui Z, Li J, De Morales PA, Marin-Manzano MC, Pardo JM, Belver A (2009) The plasma membrane $\mathrm{Na}^{+} / \mathrm{H}^{+}$antiporter SOS1 is essential for salt tolerance in tomato and affects the partitioning of $\mathrm{Na}^{+}$between plant organs. Plant Cell Environ 32:904-916

Pallotta M, Graham R, Langridge P, Sparrow D, Barker S (2000) RFLP mapping of manganese efficiency in barley. Theor Appl Genet 101:1100-1108 
Pandey P, Ramegowda V, Senthil-Kumar M (2015) Shared and unique responses of plants to multiple individual stresses and stress combinations: physiological and molecular mechanisms. Front Plant Sci 6:723

Park S, Li J, Pittman JK, Berkowitz GA, Yang H, Undurraga S, Morris J, Hirschi KD, Gaxiola RA (2005) Up-regulation of a $\mathrm{H}^{+}$-pyrophosphatase $\left(\mathrm{H}^{+}\right.$-PPase) as a strategy to engineer drought-resistant crop plants. Proc Natl Acad Sci USA 102:18830-18835

Pasapula V, Shen G, Kuppu S, Paez-Valencia J, Mendoza M, Hou P, Chen J, Qiu X, Zhu L, Zhang X (2011) Expression of an Arabidopsis vacuolar $\mathrm{H}+$-pyrophosphatase gene (AVP1) in cotton improves drought-and salt tolerance and increases fibre yield in the field conditions. Plant Biotechnol J 9:88-99

Poustini K, Siosemardeh A (2004) Ion distribution in wheat cultivars in response to salinity stress. Field Crops Res $85: 125-133$

Quintero FJ, Blatt MR (1997) A new family of $\mathrm{K}^{+}$transporters from Arabidopsis that are conserved across phyla. FEBS Lett 415:206-211

R Development Core Team (2014) R: a language and environment for statistical computing. R Foundation for Statistical Computing, Vienna. http://www.r-project.org. Accessed 1 Apr 2014

Rajendran K, Tester M, Roy SJ (2009) Quantifying the three main components of salinity tolerance in cereals. Plant Cell Environ 32:237-249

Rascher U, Blossfeld S, Fiorani F, Jahnke S, Jansen M, Kuhn AJ, Matsubara S, Märtin LL, Merchant A, Metzner R (2011) Noninvasive approaches for phenotyping of enhanced performance traits in bean. Funct Plant Biol 38:968-983

Rashid A, Qureshi R, Hollington P, Wyn Jones R (1999) Comparative responses of wheat (Triticum aestivum $\mathrm{L}$.) cultivars to salinity at the seedling stage. J Agron Crop Sci 182:199-208

Rengasamy P (2006) World salinization with emphasis on Australia. J Exp Bot 57:1017-1023

Rogowsky P, Guidet F, Langridge P, Shepherd K, Koebner R (1991) Isolation and characterization of wheat-rye recombinants involving chromosome arm 1DS of wheat. Theor Appl Genet 82:537-544

Roy SJ, Negrão S, Tester M (2014) Salt resistant crop plants. Curr Opin Biotechnol 26:115-124

Rustenholz C, Choulet F, Laugier C, Šafář J, Šimková H, Doležel J, Magni F, Scalabrin S, Cattonaro F, Vautrin S (2011) A 3,000loci transcription map of chromosome 3B unravels the structural and functional features of gene islands in hexaploid wheat. Plant Physiol 157:1596-1608

Sato Y, Nanatani K, Hamamoto S, Shimizu M, Takahashi M, TabuchiKobayashi M, Mizutani A, Schroeder JI, Souma S, Uozumi N (2014) Defining membrane spanning domains and crucial membrane-localized acidic amino acid residues for $\mathrm{K}^{+}$transport of a Kup/HAK/KT-type Escherichia coli potassium transporter. J Biochem 155:315-323

Schachtman DP, Schroeder JI (1994) Structure and transport mechanism of a high-affinity potassium uptake transporter from higher plants. Nature 370:655

Schilling RK, Marschner P, Shavrukov Y, Berger B, Tester M, Roy SJ, Plett DC (2014) Expression of the Arabidopsis vacuolar $\mathrm{H}+$-pyrophosphatase gene (AVP1) improves the shoot biomass of transgenic barley and increases grain yield in a saline field. Plant Biotechnol J 12:378-386

Segonzac C, Boyer J-C, Ipotesi E, Szponarski W, Tillard P, Touraine B, Sommerer N, Rossignol M, Gibrat R (2007) Nitrate efflux at the root plasma membrane: identification of an Arabidopsis excretion transporter. Plant Cell 19:3760-3777

Setter TL, Waters I, Stefanova K, Munns R, Barrett-Lennard EG (2016) Salt tolerance, date of flowering and rain affect the productivity of wheat and barley on rainfed saline land. Field Crops Res 194:31-42

Sewell M, Bassoni D, Megraw R, Wheeler N, Neale D (2000) Identification of QTLs influencing wood property traits in loblolly pine (Pinus taeda L.). I. Physical wood properties. Theor Appl Genet 101:1273-1281

Sewell M, Davis M, Tuskan G, Wheeler N, Elam C, Bassoni D, Neale D (2002) Identification of QTLs influencing wood property traits in loblolly pine (Pinus taeda L.). II. Chemical wood properties. Theor Appl Genet 104:214-222

Shabala S (2013) Learning from halophytes: physiological basis and strategies to improve abiotic stress tolerance in crops. Ann Bot 112:1209-1221

Shabala S (2017) Signalling by potassium: another second messenger to add to the list? J Exp Bot 68:4003-4007

Shavrukov Y, Langridge P, Tester M, Nevo E (2010) Wide genetic diversity of salinity tolerance, sodium exclusion and growth in wild emmer wheat, Triticum dicoccoides. Breed Sci 60:426-435

Shavrukov Y, Shamaya N, Baho M, Edwards J, Ramsey C, Nevo E, Langridge P, Tester M (2011) Salinity tolerance and $\mathrm{Na}^{+}$exclusion in wheat: variability, genetics, mapping populations and QTL analysis. Czech J Genet Plant 47:S85-S93

Shavrukov Y, Bovill J, Afzal I, Hayes JE, Roy SJ, Tester M, Collins NC (2013) HVP10 encoding V-PPase is a prime candidate for the barley $H v N a x 3$ sodium exclusion gene: evidence from fine mapping and expression analysis. Planta 237:1111-1122

Sirault XR, James RA, Furbank RT (2009) A new screening method for osmotic component of salinity tolerance in cereals using infrared thermography. Funct Plant Biol 36:970-977

Suchecki R, Watson-Haigh NS, Baumann U (2017) POTAGE: a visualisation tool for speeding up gene discovery in wheat. Sci Rep $7: 14315$

Sun Y, Kong X, Li C, Liu Y, Ding Z (2015) Potassium retention under salt stress is associated with natural variation in salinity tolerance among Arabidopsis accessions. PLoS ONE 10:e0124032

Takahashi F, Tilbrook J, Trittermann C, Berger B, Roy SJ, Seki M, Shinozaki K, Tester M (2015) Comparison of leaf sheath transcriptome profiles with physiological traits of bread wheat cultivars under salinity stress. PLoS ONE 10:e133322

Taylor J (2015) Efficient linkage map construction using R/ASMap. https://cran.r-project.org/web/packages/ASMap/vignettes/asmap vignette.pdf. Accessed 13 Mar 2016

Teakle NL, Tyerman SD (2010) Mechanisms of $\mathrm{Cl}^{-}$transport contributing to salt tolerance. Plant, Cell Environ 33:566-589

Tester M, Davenport R (2003) $\mathrm{Na}^{+}$tolerance and $\mathrm{Na}^{+}$transport in higher plants. Ann Bot 91:503-527

Tilbrook J, Schilling RK, Berger B, Garcia AF, Trittermann C, Coventry S, Rabie H, Brien C, Nguyen M, Tester M, Roy SJ (2017) Variation in shoot tolerance mechanisms not related to ion toxicity in barley. Funct Plant Biol 44:1194-1206

Tsay Y-F, Chiu C-C, Tsai C-B, Ho C-H, Hsu P-K (2007) Nitrate transporters and peptide transporters. FEBS Lett 581:2290-2300

Ullah A, Dutta D, Fliegel L (2016) Expression and characterization of the SOS1 Arabidopsis salt tolerance protein. Mol Cell Biochem 415:133-143

Van Os H, Stam P, Visser RG, Van Eck HJ (2005) RECORD: a novel method for ordering loci on a genetic linkage map. Theor Appl Genet 112:30-40

Wang S, Basten C, Zeng Z (2007) Windows QTL cartographer 2.5. Department of Statistics, North Carolina State University, Raleigh

Ward JM, Schroeder JI (1994) Calcium-activated K+ channels and calcium-induced calcium release by slow vacuolar ion channels in guard cell vacuoles implicated in the control of stomatal closure. Plant Cell 6:669-683 
Wyn Jones R, Brady C, Speirs J (1979) Ionic and osmotic relations in plant cells. In: Laidman DL, Wyn Jones RG (eds) Recent advances in the biochemistry of cereals. Academic Press, London

Zhao F-Y, Zhang X-J, Li P-H, Zhao Y-X, Zhang H (2006) Co-expression of the Suaeda salsa SsNHX1 and Arabidopsis AVP1 confer greater salt tolerance to transgenic rice than the single $S s N H X 1$. Mol Breed 17:341-353
Zhu J-K (2002) Salt and drought stress signal transduction in plants. Annu Rev Plant Biol 53:247-273

Zhu J-K (2003) Regulation of ion homeostasis under salt stress. Curr Opin Plant Biol 6:441-445

Zhu M, Shabala S, Shabala L, Fan Y, Zhou M (2016) Evaluating predictive values of various physiological indices for salinity stress tolerance in wheat. J Agron Crop Sci 202:115-124

\section{Affiliations}

Muhammad A. Asif ${ }^{1,2} \cdot$ Rhiannon K. Schilling $^{1,2} \cdot$ Joanne Tilbrook ${ }^{1,2,3} \cdot$ Chris Brien $^{1,4,5} \cdot$ Kate Dowling $^{1,4}$. Huwaida Rabie ${ }^{5,6}$. Laura Short ${ }^{1,2}$. Christine Trittermann ${ }^{1,2}$. Alexandre Garcia, ${ }^{1,2,4}$. Edward G. Barrett-Lennard, ${ }^{7,8}$ Bettina Berger ${ }^{2,4}$. Diane E. Mather ${ }^{2}$. Matthew Gilliham ${ }^{2,9} \cdot$ Delphine Fleury $^{1,2} \cdot$ Mark Tester $^{1,2,10} \cdot$ Stuart J. Roy ${ }^{1,2}$ (1) Allison S. Pearson ${ }^{1,2,9}$

1 Australian Centre for Plant Functional Genomics, PMB 1, Glen Osmond, SA 5064, Australia

2 School of Agriculture, Food and Wine, The University of Adelaide, PMB 1, Glen Osmond, SA 5064, Australia

3 Plant Industries Development, Department of Primary Industry and Resources, PO Box 3000, Darwin, NT 0801, Australia

4 The Plant Accelerator, Australian Plant Phenomics Facility, The University of Adelaide, Urrbrae, SA 5064, Australia

5 Phenomics and Bioinformatics Research Center, The University of South Australia, GPO Box 2471, Mawson Lakes 5001, SA, Australia

6 Bethlehem University, Rue de Freres \#9, Bethlehem, West Bank, Palestine
7 School of Agriculture and Environment (M084), The University of Western Australia, 35 Stirling Highway, Crawley, WA 6009, Australia

8 Department of Primary Industries and Regional Development, 3 Baron-Hay Court, South Perth 6151, WA, Australia

9 ARC Centre of Excellence in Plant Energy Biology, The University of Adelaide, PMB 1, Glen Osmond, SA 5064, Australia

10 Division of Biological and Environmental Sciences and Engineering, King Abdullah University of Science and Technology, Thuwal, Saudi Arabia 